\title{
A Systematic Review Describing Contextual Teaching Challenges Associated With Inquiry-Based Practical Work in Natural Sciences Education
}

\author{
Fru Vitalis Akuma ${ }^{1 *}$, Estelle Gaigher ${ }^{1}$ \\ ${ }^{1}$ Department of Science, Mathematics and Technology Education, Faculty of Education, Groenkloof Campus, University of \\ Pretoria, Private Bag X20, Hatfield 0028, SOUTH AFRICA
}

Received 3 June 2021 - Accepted 23 October 2021

\begin{abstract}
There are many challenges associated with Inquiry-Based Practical Work (IBPW), scattered in the school and post-school natural sciences education research literature. The goal of the systematic review presented in this paper, was to gather the contextual teaching challenges in the said literature, and then to create a detailed multi-perspective description of these challenges. The result shows that, the challenges occur mostly in the northern hemisphere, the highest proportion is in the Upper- and Post-secondary education levels, and more than half of the challenges are in integrated natural sciences education settings. In addition, the challenges are deeply divided between the school- and system-levels of the education framework, with the emergence of seven categories that have not been reported before. While significantly increasing knowledge, the results can be used when supporting teachers implementing IBPW. This is in addition to informing future research, around teacher support and the further unravelling of the challenges.
\end{abstract}

Keywords: contextual teaching challenges, multi-perspective description, inquiry-based practical work, systematic review, school and post-school natural sciences education

\section{INTRODUCTION}

In this paper, we present a systematic literature review relating to Inquiry-Based Practical Work (IBPW), in school and post-school natural sciences education settings. We define this type of practical work as classroom, laboratory, or field activities, in which learners interact with natural phenomena, or with data about such phenomena. This is while enhancing their understanding of scientific inquiry as they develop scientific practices. This is based on a teaching and learning strategy that goes beyond verification inquiry and towards open inquiry. In this regard, however, there are contextual teaching challenges. We consider the challenges as factors in the educational environment (for example, an inadequacy in classroom space and managerial support), that hinder the efforts of any teacher, when implementing IBPW in that environment. The challenges restrict learner access to IBPW and the associated learning benefits. The goal of the review we present in this paper, was, first, to gather the challenges which are scattered in the international literature about natural sciences education, ranging from the school to post-school level. Next, was to create a detailed multiperspective description of the challenges, in order to inform practice and further research. Below, we will begin by placing the research focus in context, before elaborating upon the focus.

\section{Background Information}

Practical work has been defined in broad terms, as classroom, laboratory, or field activities, that offer learners opportunities to directly interact with natural phenomena or with data about the phenomena, that have been gathered beforehand by other people (National Research Council, 2005a, 2006). The science education literature (Hodson, 2014; Jagodziński \& Wolski, 2015; Kidman, 2012; Millar, 2009; National Research Council, 2006), identifies a number of primary learning goals relating to practical work. The goals include learning about science concepts; the characteristics of scientific inquiry, and the nature of science; coupled with developing the practices that are needed in scientific inquiry. 


\section{Contribution to the literature}

- We have described contextual teaching challenges relating to Inquiry-Based Practical Work (IBPW) in school and post-school natural sciences education settings, from three new perspectives.

- The perspectives are geographical location, coupled with the level, and the field of natural sciences education.

- The challenges occur mostly in the northern hemisphere, with the highest proportion in the Upper- and Post-secondary education levels, and more than half in integrated natural sciences education settings.

- From an education framework perspective, seven new categories of the challenges such as quality of school texts, assessment practices, and developmental age, have emerged.

While scientific inquiry has been considered as a varied set of practices that scientists regularly use to address the questions they ask about the natural world (Bartos \& Lederman, 2014; Maeng \& Bell, 2013; National Science Teaching Association, 2018), the current research is associated with practical work that is orientated towards the development of these practices. The practices include asking questions, planning investigations, constructing explanations, coupled with acquiring, evaluating, and communicating information (Bell et al., 2010; National Research Council, 2012; Rönnebeck et al., 2016).

In educational contexts, the word "inquiry" does not have a unique meaning. In the literature (Bybee, 2000; Lunetta, 1998; National Research Council, 2000, 2007), one finds meanings that include 1) an instructional strategy aimed at increasing learner understandings of science concepts, coupled with 2) a learning outcome consisting of the acquisition of a) epistemological understandings of science, and b) scientific practices. The meaning of the term "inquiry" in $2 b$ ), is the meaning used in the research presented in this paper, as it coincides with the development of scientific practices primary learning goal in practical work.

In terms of the selected learning outcome and goal in practical work, classroom inquiry implementation strategies are not equally suitable. The strategies have been widely considered to consist, in principle, of verification, structured, guided, and open inquiry (Blanchard et al., 2010; Herron, 1971; Schwab, 1962). While these strategies are in order of increasing learner autonomy in the inquiry activity, open inquiry best allows a learner to develop scientific practices, whereas verification inquiry least supports learner development of the practices. The latter strategy is also referred to as the confirmatory, teacher-centred, and traditional strategy in practical work. Although Sadeh and Zion (2012) acknowledge that this strategy is effective in the development of observation, data gathering, inference generation and other basic science skills, some researchers (Nedungadi et al., 2015; Sadeh \& Zion, 2012; Zion \& Mendelovici, 2012) exclude verification inquiry when discussing classroom inquiry implementation strategies. Since verification inquiry involves a science question, data collection methods, and the interpretation of results all from the teacher (Abrams et al., 2007; Schwab, 1962), this strategy is actually not in line with the earlier noted meanings of the term "inquiry" in educational settings. In this light, and with reference to practical work, Bowen et al. (2018), argue that verification-based practical work does not involve inquiry. Thus, we consider the term verification-based practical work to mean classroom, laboratory, or field activities, in which learners interact with natural phenomena, or with data about such phenomena, with a focus on basic science skills such as observation and data collection, coupled with the verification of science concepts, in a teacher-driven manner.

The current research rather focused on practical work involving the critical engagement of learners, in line with the view presented by Bowen et al. (2018), and the description given by Sesen and Tarhan (2013) to an inquiry-based laboratory activity. This is a learning experience which not only engages learners in activities such as observing events and objects, but also asking questions, designing investigations, suggesting explanations, gathering and analyzing data, coupled with comparing suggested explanations with fresh evidence. Terms that some authors have used for such activities include science inquiry work (So, 2013), inquiry-based learning activities (Chairam et al., 2015), practical enquiry activities (Toplis \& Allen, 2012), and Inquiry-Based Practical Work (IBPW) (Kim \& Tan, 2010). We have used the term IBPW in the current research, to mean classroom, laboratory, or field activities, in which learners interact with natural phenomena, or with data about such phenomena, with emphasis on the development of scientific practices, based on a strategy that goes beyond verification inquiry and towards open inquiry. Thus, IBPW excludes verification-based practical work.

There is evidence of the learning benefits of IBPW in the literature. For example, Lavonen and Laaksonen (2009) found that the drawing of conclusions is a predictor of high learning outcomes in Finland. In the context of Israel, secondary school science students who took part in IBPW, were found to ask better questions, to better plan when dealing with variables in an experiment, in addition to making suggestions 
regarding more reliable and valid equipment (Hofstein \& Lunetta, 2004).

\section{Research Focus}

Verification-based practical work, is predominant in many countries as evidenced by the natural sciences education literature (Abrahams \& Millar, 2008; Childs et al., 2012; Di Fuccia et al., 2012; Ramnarain \& Schuster, 2014; Sandoval et al., 2016). Although there is value in this type of practical work, its predominance is at the expense of IBPW, and may be obscuring challenges associated with IBPW.

Many teaching challenges associated with IBPW can be found in a scattered manner, in the international school and post-school natural sciences education research literature (Crawford, 2016; Duangpummet et al., 2019; Lederman \& Lederman, 2012; Ramnarain, 2016). Although some of the challenges are teacherbased (Duangpummet et al., 2019; Ramnarain, 2016), the focus in the presented research was on the contextual challenges. We consider contextual teaching challenges relating to IBPW as factors in the educational environment (for example, an inadequacy in classroom space and managerial support), that hinder the efforts of any teacher, when implementing IBPW in that environment.

Limited research has been conducted to yield a detailed description of the challenges. Akuma and Callaghan (2019) provide a description based on a case study of physical science classrooms in two schools, and from the education framework perspective. In many countries, the framework consists of a national, regional, and school level. The case study yielded a description of the challenges that is a function of the specific challenges that were found in the research context. Although a description incorporating the many challenges that have been found in other contexts would enhance knowledge about the challenges, such a description is currently lacking. There is also the lack of a description incorporating other perspectives that researchers have used in the description of educational phenomena. An example is the level of education perspective, with levels ranging from early childhood education to the doctoral or an equivalent level (Minner et al., 2010). Another perspective is the field of education perspective (Park \& Liu, 2016), involving for example, the physical sciences, environment, coupled with the biological and related sciences.

Given the discussion in the preceding paragraphs, the goal of the systematic review presented in this paper, was to gather the contextual teaching challenges relating to IBPW that are scattered in the international school and post-school natural sciences education research literature, and then to create a detailed multi-perspective description of the challenges. The description is an aggregation of the accumulated and dispersed international evidence about contextual teaching challenges relating to IBPW. As seen later in section Discussion and Conclusions, the description expands knowledge regarding the challenges, allows for both a sector-wise and systemic approach in addressing the challenges, while suggesting lines in future research.

\section{CONCEPTUAL FRAMEWORK}

\section{Elaborating a Definition of Contextual Teaching Challenges for the Current Research}

First of all, Schoepp (2005) defined a teaching challenge as a situation that hinders a teacher when working towards an outcome. In the current research, the 'outcome' is the successful implementation of IBPW. Regarding 'a situation that hinders a teacher' from reaching this outcome, Akuma and Callaghan (2019) considered hindrances associated with the physical, cultural, and social characteristics of an educational environment. An example of a cultural hindrance is found in Toplis and Allen (2012), who note that due to the high stakes assessment culture, IBPW is being limited to a few verified investigative activities that are disconnected from routine science instruction. Regarding a physical hindrance, we see in Kidman (2012), that some teachers cited limitations in classroom space as a key hindrance associated with the enactment of IBPW. In terms of the social characteristics of the educational environment, inadequate managerial support is a hindrance regarding the enactment of IBPW (Huziak-Clark et al., 2007; Ramnarain, 2011). Although space limitations and inadequate managerial support may occur only in some classrooms and schools, respectively, the same is not true of a high-stakes assessment culture. The environment in which teachers work, goes beyond a specific school (Clarke \& Hollingsworth, 2002), to include the regional and national levels of the education framework, as seen later within section Education framework perspective. Contextual teaching challenges linked to IBPW can emanate from many aspects of this extensive professional environment.

Contextual teaching challenges can also be thought of, as challenges that emanate from outside what Clarke and Hollingsworth (2002) refer to as the personal domain of teachers. The personal domain, consists of intrinsic teacher attributes such as professional knowledge, beliefs and attitudes. For some teachers, there may be challenges linked to IBPW that are associated to these attributes. These would be teacherbased, and not contextual challenges, one of which Ramnarain (2016) identified as inadequate pedagogical content knowledge. In contrast to such challenges, a contextual challenge affects all teachers working in the context in which the challenge occurs. This makes limitations in classroom space, inadequate managerial support, a high-stakes assessment culture, examples of 


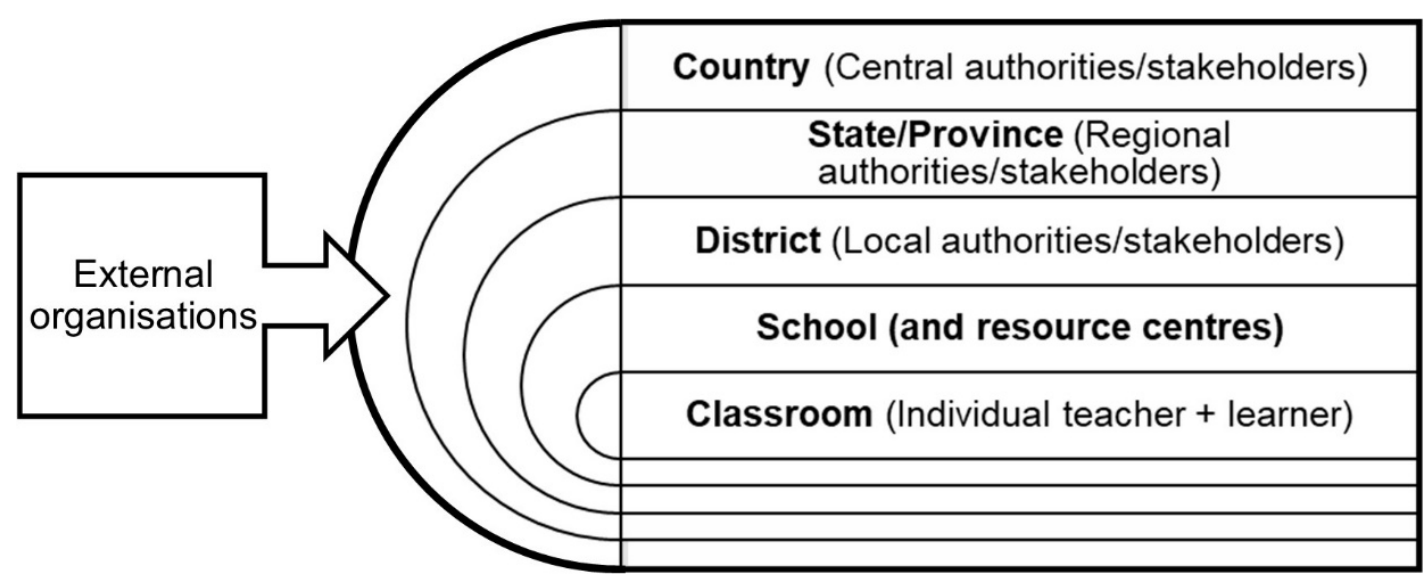

Figure 1. An education framework as occurs in many countries

contextual teaching challenges associated with IBPW at the classroom, school, and regional/national levels, respectively. Thus, we define a contextual teaching challenge relating to IBPW, as a context-based factor (for example, an inadequacy in classroom space and managerial support), that hinders the efforts of a teacher, in relation to the implementation of IBPW.

\section{Perspectives Useful in Describing Contextual Teaching Challenges Relating to IBPW}

Firstly, it has been noted that education is a complex endeavour, with multiple facets (Elmore, 1996). It is thus natural that educational phenomena have been described from different perspectives. The question here is that of the perspectives that may be used in creating a detailed description of contextual teaching challenges associated with IBPW. In this regard, we discuss the geographical location, education framework, level of education, and field of education perspectives.

\section{Geographical location perspective}

The country of origin of the research, has been used by some researchers when describing educational phenomena (Abelha et al., 2020; Heradio et al., 2018; Plomp \& Nieveen, 2013). However, as Plomp and Nieveen (2013) note, the geographical location of the research must not be mistaken for the country where the researchers live. Also worthy of note, is the fact that some researchers rather specify the applicable continent when reporting the geographical location of the research. An example is Khan (2011), who reports the geographical location as North America. Different contextual challenges may be found in the same geographical location, such as Europe (Kennedy, 2013; Toplis \& Allen, 2012), while similar challenges may be found in very different locations such as Africa and Asia (Childs et al., 2012; Kriek \& Grayson, 2009).

\section{Education framework perspective}

Figure 1 illustrates the education framework in the context of many countries around the world, as reported in a number of literature sources (ET 2020 Working Group on Schools, 2018; Makoelle, 2012; National Research Council, 2015; Tichnor-Wagner et al., 2019).

In the framework in Figure 1, there are multiple interacting levels, a shared vision, the setting of expectations in the higher levels, and efforts to shape the system from lower levels (ET 2020 Working Group on Schools, 2018). The organisations mentioned in the left of the figure, include non-governmental educational institutions that create instructional materials (e.g., curriculum units and textbooks), or provide professional development.

Associated with the framework in Figure 1, are specific levels, as seen in the literature (Akuma \& Callaghan, 2019; Jones, 2004). The levels consist of the system-level (national, state, or district), coupled with the school level. The scarcity of inquiry-based practical activities in some school science textbooks (Abd-ElKhalick et al., 2004; Crawford, 2016), is a system-level contextual teaching challenge associated with IBPW. The lack of valuing of classroom inquiry by some staff leaders (Huziak-Clark et al., 2007), is a school-level contextual teaching challenge.

System-level and school-level teaching challenges have been found to be material-related and/or nonmaterial-related (Akuma \& Callaghan, 2019; Pelgrum, 2001). The preceding examples are, material-related and non-material-related challenges, respectively.

\section{Level of education perspective}

Researchers have also described educational phenomena from the perspective of the level of education (Minner et al., 2010; Plomp \& Nieveen, 2013). This perspective is reflected in the term "education sector" used by Plomp and Nieveen (2013). The International Standard Classification of Education (ISCED) offers a harmonised framework of levels, coupled with fields of education and training. The nine levels of education in ISCED 2011, are contained in the first two columns in Table 1 (UNESCO Institute of Statistics, 2020). The table also shows the mapping of the 
Table 1. Mapping ISCED 2011 levels of education to two countries (UNESCO Institute of Statistics, 2020)

\begin{tabular}{|c|c|c|c|c|}
\hline \multirow[b]{2}{*}{ ISCED 2011 Level } & \multicolumn{2}{|l|}{ South African equivalent } & \multicolumn{2}{|l|}{ United States equivalent } \\
\hline & Name & $\begin{array}{l}\text { Theoretical } \\
\text { starting age }\end{array}$ & Name & $\begin{array}{l}\text { Theoretical } \\
\text { starting age }\end{array}$ \\
\hline $\begin{array}{l}0 \text { Early childhood } \\
\text { education }\end{array}$ & Grade R & 5 & $\begin{array}{l}\text { Preschool or pre-kindergarten/ } \\
\text { Kindergarten }\end{array}$ & $\begin{array}{l}2-4 \\
4-6\end{array}$ \\
\hline 1 Primary education & Primary education (Grades 1 - 7) & 7 & Primary education & $5-7$ \\
\hline $\begin{array}{l}2 \text { Lower secondary } \\
\text { education }\end{array}$ & $\begin{array}{l}\text { Lower secondary education } \\
\text { (Grades } 8 \text {-9) }\end{array}$ & 14 & Middle education (Grades 7 - 9) & $11-13$ \\
\hline $\begin{array}{l}3 \text { Upper secondary } \\
\text { education }\end{array}$ & $\begin{array}{l}\text { e.g., Further education training } \\
\text { band (Grades } 10-12)\end{array}$ & 16 & $\begin{array}{l}\text { H.S. Equivalency Programme / } \\
\text { Secondary education (Grades } 10 \text { - 12) }\end{array}$ & $\begin{array}{c}16+/ \\
14-17\end{array}$ \\
\hline $\begin{array}{l}4 \text { Post-secondary non- } \\
\text { tertiary education }\end{array}$ & e.g., National Higher certificate & 19 & Certificate Program & $18-30$ \\
\hline $\begin{array}{l}5 \text { Short-cycle tertiary } \\
\text { education }\end{array}$ & National Diploma & 20 & $\begin{array}{l}\text { e.g., Academic Associate's Degree } \\
\text { Programme }\end{array}$ & $18-30$ \\
\hline $\begin{array}{l}6 \text { Bachelor level education } \\
\text { and equivalent }\end{array}$ & $\begin{array}{l}\text { e.g., Bachelor's and Advanced } \\
\text { diploma }\end{array}$ & 19 & $\begin{array}{l}\text { e.g., Post-bachelor's certificate } \\
\text { programme (e.g. teaching) }\end{array}$ & $22-30$ \\
\hline $\begin{array}{l}7 \text { Master's or equivalent } \\
\text { level }\end{array}$ & Master's & 24 & $\begin{array}{l}\text { e.g., First Professional Degree } \\
\text { Programme }\end{array}$ & $22-30$ \\
\hline $\begin{array}{l}8 \text { Doctoral or equivalent } \\
\text { level }\end{array}$ & $\begin{array}{l}\text { Doctorate degree/Laureatus in } \\
\text { Technology (Technikon) }\end{array}$ & 26 & Doctorate (Ph.D. - Research) & $24-32$ \\
\hline
\end{tabular}

break down, in the case of two countries used as examples.

Table 1 can serve as a basis for describing contextual teaching challenges associated with IBPW in relation of the level of education in which the challenges were reported. For example, consider the case of the increased time needed for course completion and revision resulting from the integration of inquiry in practical work in the Junior Certificate science programme in Ireland (Higgins, 2009). This is a lower secondary education level (ISCED level 2) challenge linked to IBPW, in the given context. This is because the programme spans the first three years of post-primary education, and is commenced at an age of at least 12 years (National Council for Curriculum and Assessment, 2008). As a second example, Ramnarain and Schuster (2014) found in their research in high school physical sciences classrooms, that the lack of science education equipment is a challenge when attempting to implement IBPW. This challenge lies in the Upper secondary education level (ISCED level 3 in Table 1), since as seen in Department of Basic Education (2011), physical science is taught in grades 10 to 12 .

\section{Field of education perspective}

This is another perspective that has been used by many researchers when describing educational phenomena (Park \& Liu, 2016; Rutten et al., 2012). The ISCED for fields of education and training, identifies broad, narrow, and detailed fields of education and training (UNESCO, 2014). One of the broad fields is natural sciences, mathematics and statistics (Table 2).

We can use Table 2 when describing challenges associated with IBPW from the field of education perspective. From this perspective, the examples of
Table 2. Broad, narrow, and detailed fields of education involving the natural sciences (UNESCO, 2014)

\begin{tabular}{lll}
\hline Broad field & Narrow field & Detailed field \\
\hline 05 Natural & 051 Biological and & 0511 Biology \\
sciences, & related sciences & 0512 Biochemistry \\
\cline { 2 - 2 } $\begin{array}{l}\text { mathematics } \\
\text { and statistics }\end{array}$ & 052 Environment & 0521 Environmental \\
& & $\begin{array}{l}\text { sciences } \\
\text { 0522 Natural environments }\end{array}$ \\
& & and wildlife \\
& 053 Physical & 0531 Chemistry \\
& sciences & 0532 Earth sciences \\
& 054 Mathematics & 0533 Physics \\
\hline & and statistics & 0541 Mathematics \\
\end{tabular}

contextual challenges linked to IBPW from Higgins (2009), and Ramnarain and Schuster (2014), as seen in the end of the preceding section, can be considered to lie in the natural sciences broad field (Field 05) and the physical sciences narrow field (Field 053), respectively. Although this is obvious in the case of the example from Ramnarain and Schuster (2014), further information may be needed in relation to the Junior Certificate science programme in Ireland. The programme combines biology, chemistry and physics (National Council for Curriculum and Assessment, 2008), as a result of which the said challenge falls under Field 05 in Table 2.

The discussion in this section, illustrates how it is possible to create a description of contextual teaching challenges associated to IBPW, from four perpectives that have been used before, to describe educational phenomena. It may be worth noting that these perspectives are mutually exclusive, since given sufficient information, each contextual teaching challenge linked to IBPW, can be positioned in each of the different perspectives. As an example, consider the 


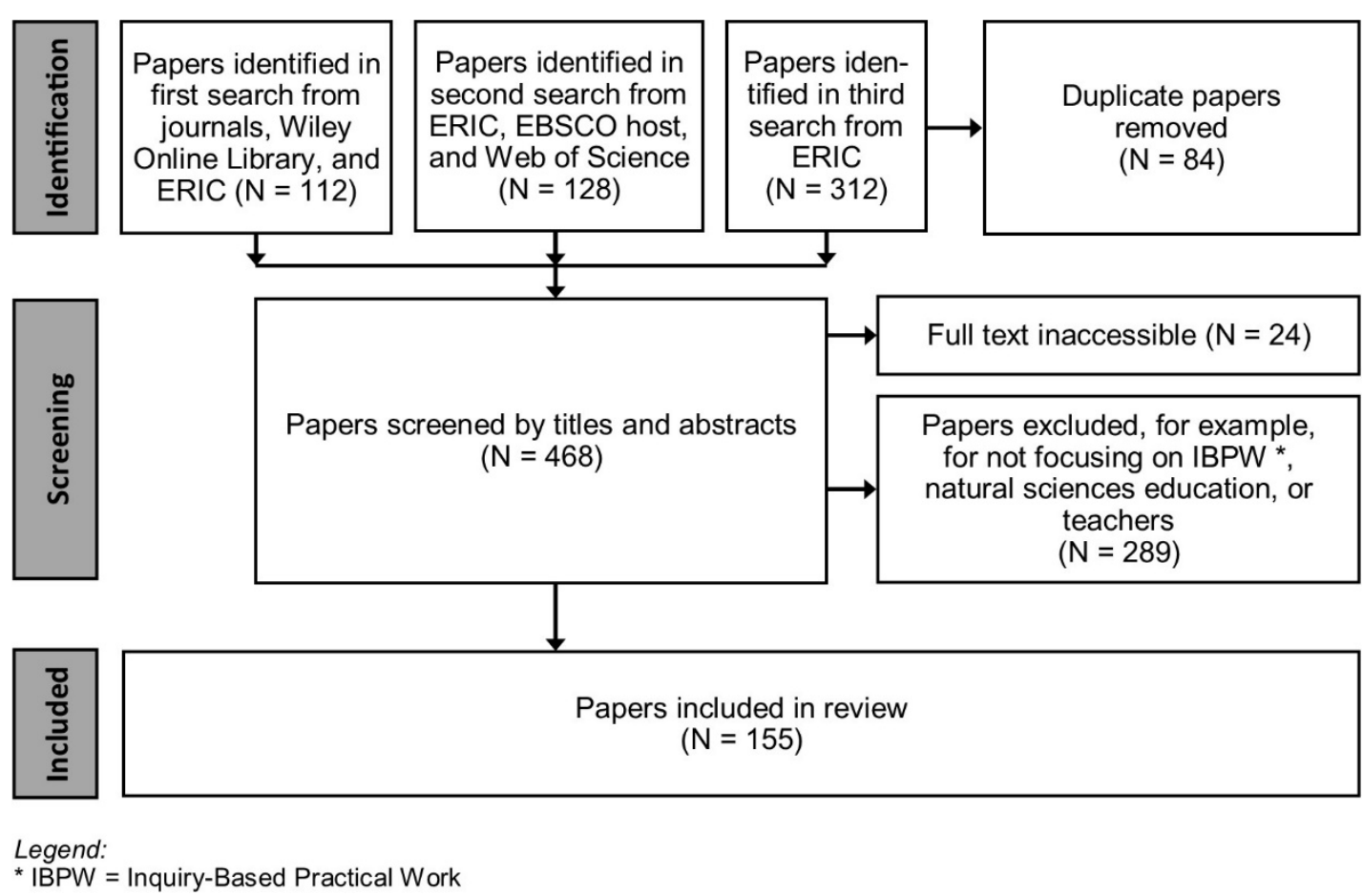

Figure 2. Summary of paper identification and screening (Adapted from the PRISMA 2020 flow diagram in Page et al., 2021)

challenge found by Ramnarain and Schuster (2014) in their research in high school physical sciences classrooms, that the lack of science education equipment is a challenge when attempting to implement IBPW. This challenge is identified in Africa (geographical location), in the physical sciences (field of education), in the Upper secondary education level (level of education), and is a school-level challenge (level of education framework).

Considering the purpose of the current research, we will next describe how we gathered the contextual challenges as defined in section Elaborating a Definition of Contextual Teaching Challenges for the Current Research, and then analysed them as illustrated throughout section Perspectives Useful in Describing Contextual Teaching Challenges Relating to IBPW, to create the desired detailed multi-perspective description of these challenges.

\section{METHODOLOGY: A SYSTEMATIC REVIEW}

A systematic review has been described as a review of the literature, that closely adheres to a set of techniques aiming to reduce bias in the identification, evaluation, and synthesis of all related research, in an effort to respond to one or more given questions (Petticrew \& Roberts, 2006). In the presented research, the literature is the international school and post-school natural sciences education research literature regarding IBPW, while the question is that of a detailed multiperspective description of the contextual teaching challenges linked to IBPW, that are found in this literature.
We carried out the systematic review, with reference to the Preferred Reporting Items for Systematic Reviews and Meta-Analyses (PRISMA) 2020 checklist (Page et al., 2021). We incorporated the guidelines in relation to reviews in the field of education that reflect the guidelines (Abelha et al., 2020; Henderson et al., 2011; Martin et al., 2019). In this regard, the first step was to state the goal of the literature review, which is to gather the contextual teaching challenges relating to IBPW that are scattered in the international school and post-school natural sciences education research literature, and then to create a detailed multi-perspective description of the challenges (section Research focus). The other steps which follow, go from searching for related research papers, to extracting and analysing the data.

\section{Searching for Related Research Papers}

To identify suitable papers, we conducted three searches, with the second and third searches meant to expand upon, and update the initial search. The searches are summarized in the first row in Figure 2. The total return from the three searches, was 552 papers including 84 duplicates. A detailed description of the three searches follows.

The first search was in 2017 and involved six online databases, of which three were journal databases. To the journal databases, we added Wiley Online Library and ERIC, to diversify the databases we used. The search terms were 'secondary school' AND 'science education' AND 'laboratory work' OR 'practical work' AND 'inquiry-based' AND 'investigative'. Thus, although this first search was restrictive in relation to the level of 
education (a weakness we addressed in subsequent searches), it was open in relation to the fields of natural science, geographical location, and education framework. While applying the search terms in the full text of the papers, we retained only papers with publication dates going back to 2007, as we desired at the time, to include only research that was within a ten-year period prior to the search date, in line with Rutten et al. (2012). The resulting search list contained 112 papers.

We carried out the second search for research papers in March 2019, in ERIC, EBSCO host, and Web of Science. This was based on the search terms we used before. However, to expand the data collection, this time, we did not restrict the search to the secondary school level, while also lowering the lower limit of the publication date range to 2000. Taking the case of EBSCO host as an example, the search settings we used were English (Language), January 2000 to February 2019 (publication date range), Full pdf-text available, Peer-reviewed journals, and Find all my search terms (Method). The search results from this second search consisted of 128 papers.

We conducted a third search for research papers to update and further expand the data collection in October 2019. The search was carried out in ERIC, in line with the criteria used in the second search. The result of the third search, was a list of 312 papers. This brings the total number of papers in the three search lists to 552. However, there were 84 duplicates, leaving 468 unique papers in the three search lists combined.

\section{Screening the Search List for Papers to Include}

This step which is summarised in the middle and bottom of Figure 2, started with a check of the availability of the full text of the 468 unique papers from the search for papers. After excluding 24 papers whose full text was not readily available, we screened the titles and abstracts of each of the remaining 444 papers, with reference to the search criteria noted earlier. In the process, we excluded many papers for not focussing on IBPW (e.g., Talanquer et al., 2015). We also excluded papers such as Corlu and Aydin (2016), which rather focussed on student self and peer assessment in mathematics and engineering education. We also found that many of the papers were not specifically on natural sciences education. Examples are papers focusing on vocational education (Boldrini et al., 2019), and active learning in general (Di Biase, 2019). In the end, the number of papers we could include from the three searches were 71,54 , and 30 , respectively, bringing the total to 155 papers included in the current systematic review.

\section{Coding the Included Papers}

In order to identify the characteristics of the set of included papers, we used the following four mutually exclusive perspectives, according to the theoretical frame in section Perspectives Useful in Describing Contextual Teaching Challenges Relating to IBPW, to code the papers: geographical location (section Geographical location perspective), education framework (section Education framework perspective, Figure 1), level of education (section Level of education perspective, Table 1), and field of education (section Field of education perspective, Table 2). Since review papers involve research conducted in many different geographical locations, we did not code these papers in relation to geographical location. In general, we coded the 155 included papers to yield a coding sheet that is illustrated in Figure 3. The coding sheet shows, for example, that

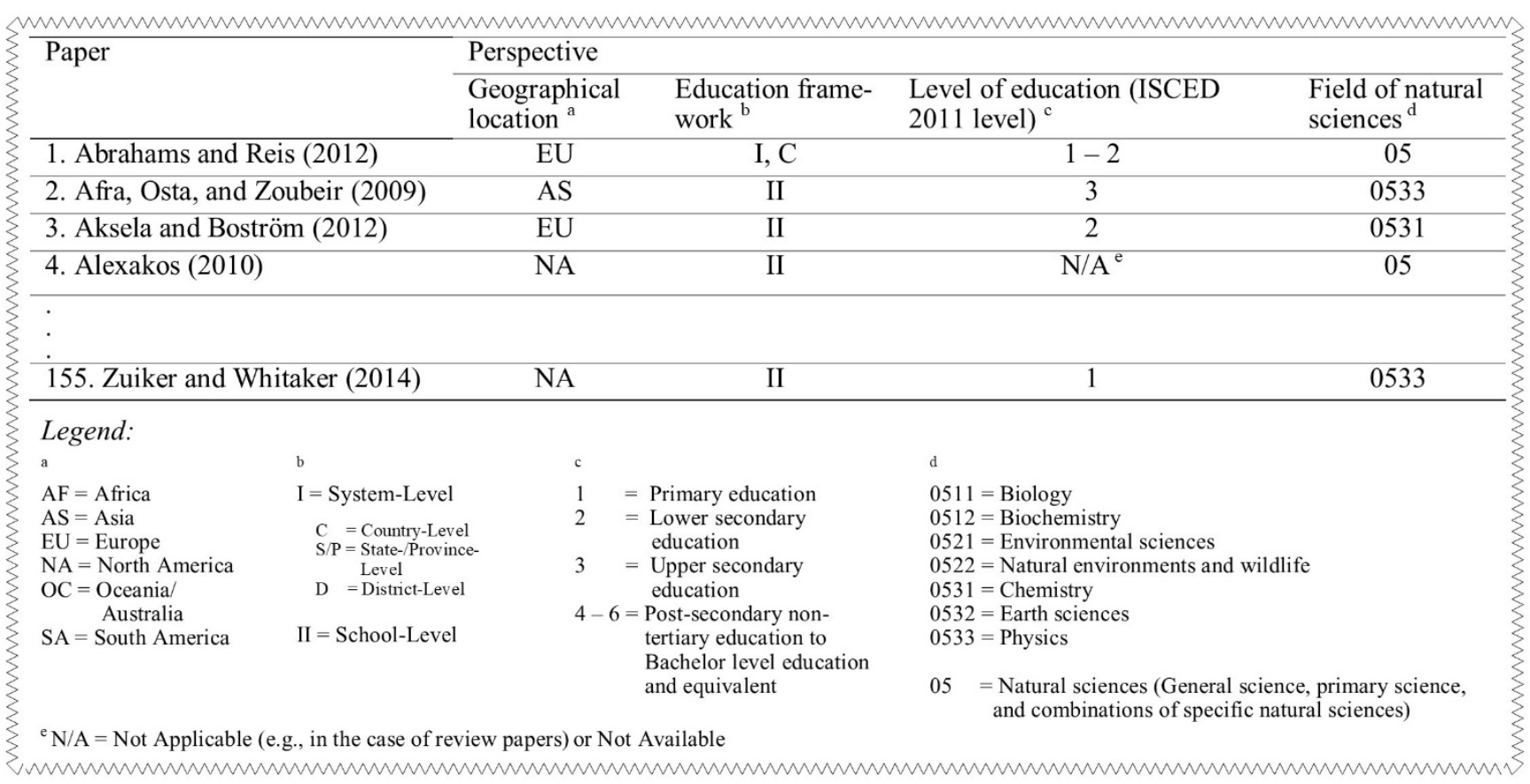

Figure 3. Excerpt of coding sheet for the included papers 


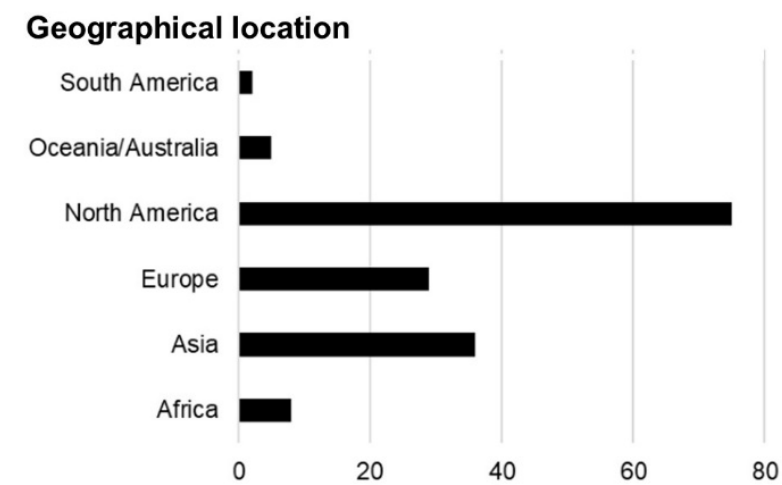

Level of education ${ }^{b}$

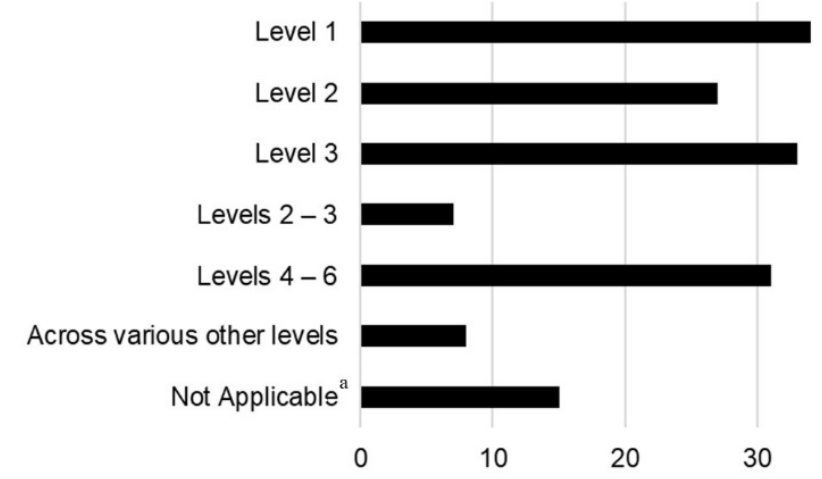

\section{Education framework}

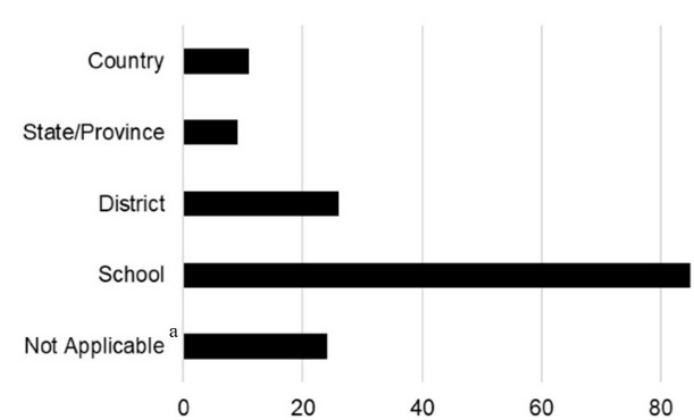

\section{Field of education}

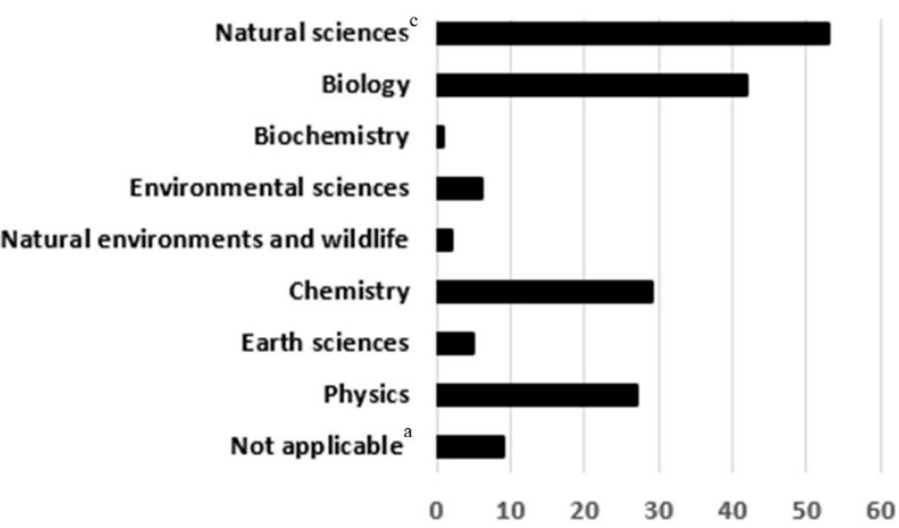

Legend:

a b

This is in the case in review papers, for example.

Level 1 = Primary education

Level 2 = Lower secondary education

Level 3 = Upper secondary education

Levels 4-6 = Post-secondary non-tertiary education to Bachelor level education and equivalent

General science, primary science, or combinations of specific natural sciences

Figure 4. Characteristics of the included papers, from four perspectives

the first paper involves research carried out in Europe, at the system level country wide. Also, the research is at the primary to lower secondary education level, and in integrated natural sciences education settings.

By analysing the data in the coding sheet, we obtained the characteristics in Figure 4, for the 155 papers included in this systematic review.

In the top left of Figure 4, we see that although a relatively large proportion of the included papers come from North America, and also from Europe and Asia, a few come from the southern hemisphere. Overall, the figure shows that the included papers are diverse, in terms of falling in several categories, in each of the four perspectives covered. Thus, the coding of the set of 155 included papers, largely confirms the comprehensiveness, and thus the suitability of the set of papers, for use in this systematic review.

\section{Extracting and Analysing the Data}

First, we note that in this systematic review, data consisted of contextual teaching challenges associated with IBPW, with the challenges being factors in the educational environment (for example, an inadequacy in classroom space and managerial support), that hampers the efforts of any teacher, when implementing IBPW in that environment (section Elaborating a Definition of Contextual Teaching Challenges for the Current Research). Considering IBPW as practical work involving a strategy that goes beyond verification inquiry and towards open inquiry, contextual teaching challenges associated with verification-based practical work were not included as data in the current research.

To extract the contextual challenges linked to IBPW, we first read each of the 155 papers in detail. Only 66 articles yielded one or more challenges. We coded each challenge in the form $C X x$, where " $C$ " stands for the word "Challenge", uppercase $X$ is a serial number $(1,2$, 3 , and so on), and lowercase $x$, is a lowercase letter ( $a, b$, $c$, and so on), used in cases where the same challenge is reported in different studies. The coding of the challenges in this way, is found in the first two columns in Appendix, which shows the challenge that each code 
Table 3. An illustration of the categorization of the contextual challenges

\begin{tabular}{|c|c|c|c|}
\hline \multirow{2}{*}{ Perspective } & \multicolumn{2}{|c|}{ Examples of deductively-generated categories } & Examples of inductively-generated categories \\
\hline & Primary & Secondary & Tertiary \\
\hline \multirow{4}{*}{$\begin{array}{l}\text { Education } \\
\text { framework }\end{array}$} & \multirow[t]{2}{*}{ School-level } & Material related & Physical resources \\
\hline & & Non-material related & Learner-related difficulties \\
\hline & \multirow[t]{2}{*}{ System-level } & Material related & Quality of school texts \\
\hline & & Non-material related & Curriculum design \\
\hline Geographical & Africa & & \\
\hline location & Europe & & \\
\hline Field of education & $\begin{array}{l}\text { Physical science } \\
\text { Biology }\end{array}$ & & \\
\hline Level of education & $\begin{array}{l}\text { Lower secondary education } \\
\text { Upper secondary education }\end{array}$ & & \\
\hline
\end{tabular}

represents. In addition to serving as an inventory of the challenges, with a description of each, Appendix plays an important role in the data analyses and in the presentation of the results of the analyses.

The analyses of the coded challenges, involved both descriptive statistics and qualitative analysis, in line with Minner et al. (2010). In the qualitative analysis, we used the two strategies in thematic analysis, beginning with the $a$ priori template of codes strategy (Crabtree \& Miller, 1999), which proceeds from a theory to a phenomenon and is thus deductive. The second strategy, being inductive and data-driven (Boyatzis, 1998), proceeds from a phenomenon to a theory.

With reference to the deductive strategy, we first defined a priori categories of contextual teaching challenges. In the field of education perspective, the categories were from Table 1, in terms of the natural sciences, while in the level of education perspective, the categories were those in the first two columns in Table 2. This was coupled with the system-level and school-level categories from the education framework perspective (section Education framework perspective). In the systemlevel and school-level primary categories, materialrelated and non-material-related challenges were the secondary a priori categories.

In continuation of the data analyses, we assigned each identified contextual teaching challenge to the applicable category in each of the four perspectives as seen in the last four columns in Appendix. It is worth bearing in mind as explained in the end of section Conceptual Framework, that the four perspectives are mutually exclusive, as a result of which every challenge was assigned to a category under each perspective.

After assigning all the identified challenges as noted, the data analyses could proceed inductively, to yield emergent categories of the challenges. However, we found that this aspect of the data analysis was meaningful in the case of the education framework perspective only. Table 1 and Table 2, already provide the basis for a detailed description of the challenges from the level of education, and field of natural sciences education perspectives, respectively. Regarding the geographical location perspective, the information in this regard in most research papers is usually rather broad, to protect the identity of participating institutions and respondents. As a result, the challenges could not be inductively analysed from this perspective as well.

The deductive coding is illustrated in the first three columns in Table 3, while inductive coding is illustrated in the fourth column, which contains examples of inductively-generated categories of the challenges.

To yield the inductively-generated categories of challenges that are exemplified in the last column in Table 3, we utilised the method of constant comparison due to Strauss and Corbin (1990), with the specific challenges in each secondary category of the challenges. In the process, we found some challenges to be identical, although reported in different research contexts. For example, see $\mathrm{C} 1 \mathrm{a}$, and $\mathrm{C} 1 \mathrm{~b}$ in Appendix. We also found similarities in some of the challenges, allowing the inductively-generated tertiary categories of the challenges to emerge from the data.

After the deductive and inductive qualitative data analyses, we generated descriptive statistics in line, for example, with Rutten et al. (2012). The statistical analysis involved counting the challenges in each deductivelyand inductively-generated category.

\section{RESULTS}

The detailed multi-perspective description of contextual teaching challenges relating to IBPW from our systematic literature review, involves 47 unique challenges. With 13 of the challenges occurring in more than one geographical location, there are 66 occurrences of the challenges. The description of these challenges that we present in this section, is based on Appendix, as noted in the preceding section. We first present the deductively-generated aspect of the description of the challenges. The inductively-generated aspect, which is from the education framework perspective only, as explained within section Extracting and Analysing the Data, then follows.

In both aspects of the description, we have used the codes of specific challenges, described in section 


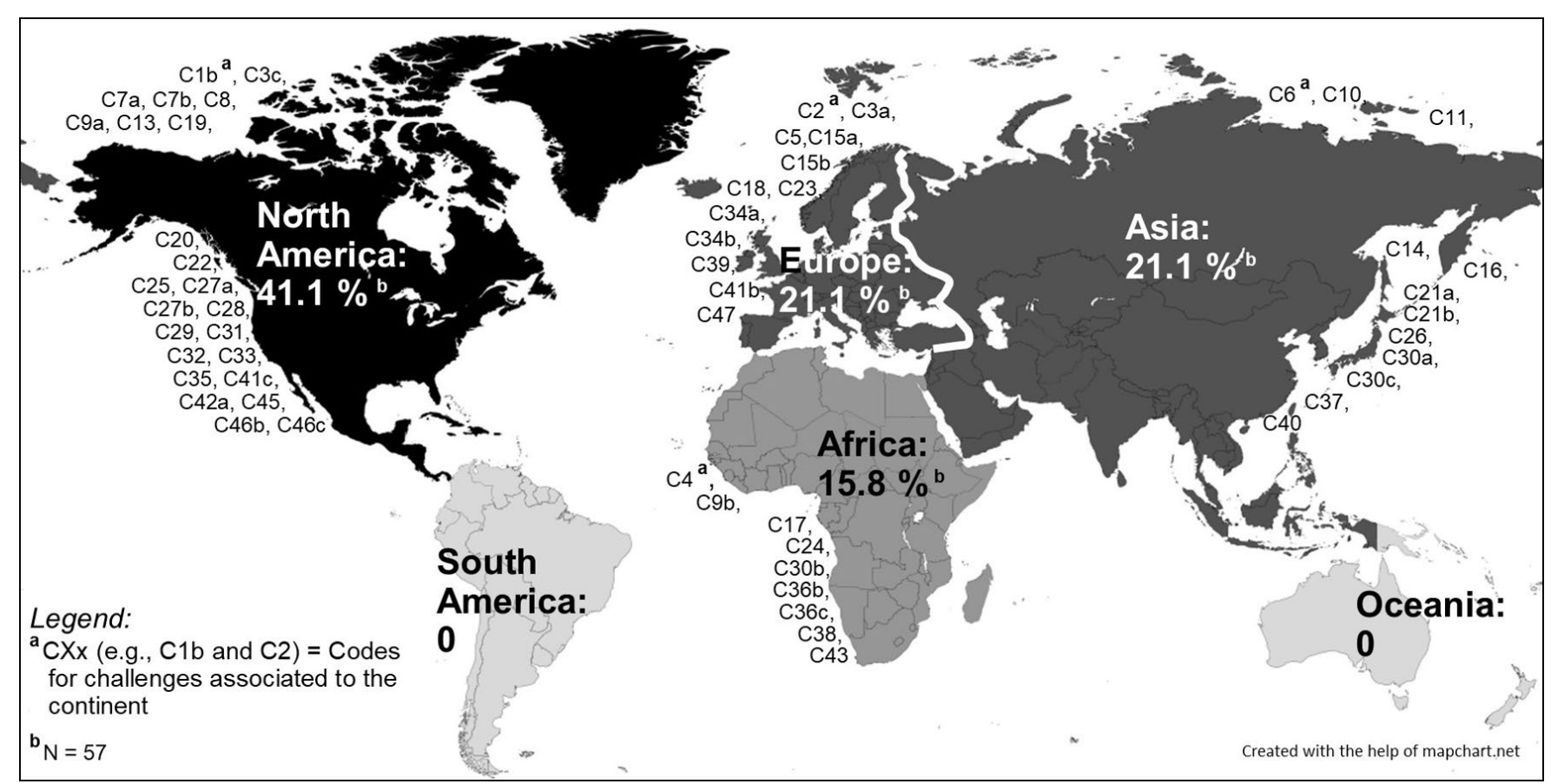

Figure 5. Distribution of the contextual teaching challenges linked to IBPW by geographical location

Extracting and Analysing the Data, and in relation to Appendix. Specifically, much of the description may need to be read in conjunction with the first two columns in Appendix.

\section{Deductively-Generated Description of the Challenges}

\section{Geographical location perspective}

In this regard, although the 47 challenges have 66 reported occurrences, we could not find the geographical location of nine of the occurrences, with the available information. The geographical locations for the remaining 57 occurrences are widely distributed across much of the globe, although mostly in the northern hemisphere (Figure 5). The largest proportion of the identified locations occur in North America, which accounts for about $41 \%$ of the challenges, while Europe and Asia harbour nearly $21 \%$ of the challenges each. While almost $16 \%$ of the located challenges occur in Africa, we did not locate any of the challenges in South America and Australia/Oceania. Although we didn't find the geographical location for nine of the challenges and didn't locate any of the remaining challenges in South America and Oceania, the located challenges are nevertheless widely distributed by being spread over four continents, especially in the northern hemisphere.

Read in conjunction with the first two columns in Appendix, Figure 5 shows the continent where particular challenges have been reported. For example, C26, which says the activities in manuals for practical work are usually restricted to structured inquiry, is one of the twelve challenges reported in Asia, as can be seen in the top right of Figure 5.

\section{Level of education perspective}

We could not determine the level of education in which more than a fifth of the 47 challenges fall, as seen at the bottom of Table 4 . However, we found that the remaining challenges are diverse in terms of the level of education in which they fall. This is as they span the Primary to Post-secondary education levels, with many identified in research that cuts across levels of education, as seen towards the top and the lower middle, in Table 4. The specific levels with the highest proportion of the challenges are the Upper- and Post-secondary education levels with about $18 \%$ of the challenges each, while the specific level with the lowest proportion of the challenges is the Primary education level, with about 8 $\%$ of the challenges.

In each of the different levels and range of levels of education, the codes for the specific challenges occurring in the level, are listed in the last column on the right, in Table 4. Based on the codes and Appendix, the challenges in the different levels of natural sciences education can be identified. For example, C45 which is reported in the primary education level, says the unavailability of equipment (e.g., hot plate) limits the investigations that teachers can allow their learners to perform.

\section{Field of education perspective}

We could not identify the field of natural sciences education for about a fifth of the 66 occurrences of the 47 contextual teaching challenges, based on the available information. Regarding the remaining occurrences of the challenges, more than half are in integrated natural sciences education settings, as seen on the left, in the last row in Table 5. A relatively much smaller proportion of 
Table 4. Description of contextual challenges regarding IBPW a from the level of education perspective

\begin{tabular}{lcl}
\hline Category & $\begin{array}{c}\text { Proportion of } \\
\text { challenges }(\%)\end{array}$ & Specific challenges b \\
\hline Primary education & 7.6 & C1b, C20, C41b, C45 and C46 \\
Lower secondary education & 10.6 & C5, C9b, C15a, C18, C34b, C39, and C47 \\
Upper secondary education & 18.2 & C4, C6, C11, C13, C17, C19, C22, C24, C26, C37, C38, and C43 \\
Post-secondary education & 18.2 & C3c, C9a, C14, C25, C27a, C27b, C30b, C32, C33, C36c, C40, and C41c \\
Across several levels & 18.2 & C2, C3a, C7b, C10, C16, C21a, C21b, C23, C30a, C31, C34a, C35, C36b, and C42a \\
Unknown level (s) c & 24.2 & C1a, C3b, C7a, C8, C12, C15b, C28, C29, C30c, C34c, C36a, C41a, C42b, C44, \\
& & C46a, and C46b \\
\hline
\end{tabular}

a IBPW = Inquiry-Based Practical Work

b Note: The codes in the column, represent specific challenges described in Appendix

c The case of challenges picked up, for example, from review papers, while the cited paper is not accessible.

Table 5. Description of contextual challenges regarding IBPW a from field of education perspective

\begin{tabular}{lcl}
\hline Category & Proportion (\%) & Specific challenges ${ }^{\text {b }}$ \\
\hline Physics & 1.5 & C36b \\
Physical sciences & 9.1 & C4, C17, C24, C30b, C38, and C43 \\
Biology & 12.1 & C3c, C6, C11, C20, C26, C37, C41b, and C41c \\
Unknown field (s) c & 19.7 & C1a, C3b, C10, C12, C21b, C30c, C34c, C36a, C41a, C42b, C44, C46a, and C46b \\
Integrated natural sciences d & 57.6 & C1b, C2, C3a, C5, C7a, C7b, C8, C9a, C9b, C13, C14, C15a, C15b, C16, C18, C19, \\
& & C21a, C22, C23, C25, C27a, C27b, C28, C29, C30a, C31, C32, C33, C34a, C34b, C35, \\
& & C36c, C39, C40, C42a, C45, C46c, and C47
\end{tabular}

a IBPW = Inquiry-Based Practical Work

b Note: The codes in the column (for example C33 and C46c) represent specific challenges described in Appendix.

c The case of challenges picked up, for example, from review papers, while the cited paper is not accessible

$\mathrm{d}$ Examples are general science, primary science, and combinations of specific natural sciences

Table 6. Description of the contextual challenges regarding IBPW a, from the education framework perspective

\begin{tabular}{|c|c|c|c|}
\hline \multicolumn{2}{|l|}{ Category } & \multicolumn{2}{|c|}{ Proportion $(\%)$ Specific challenges ${ }^{b}$} \\
\hline Primary & Secondary & & \\
\hline $\begin{array}{l}\text { School- } \\
\text { level }\end{array}$ & $\begin{array}{l}\text { Non-material- } \\
\text { related }\end{array}$ & 19.7 & C9a, C9b, C11, C13, C18, C22, C24, C25, C27a, C27b, C32, C37, and C38 \\
\hline & Material-related & 25.8 & $\begin{array}{l}\text { C4, C7a, C7b, C14, C15a, C15b, C19, C30a, C30b, C30c, C31, C36a, C36b, C36c, } \\
\text { C40, C43, and C45 }\end{array}$ \\
\hline $\begin{array}{l}\text { System- } \\
\text { level }\end{array}$ & $\begin{array}{l}\text { Material-related } \\
\text { Non-material- } \\
\text { related }\end{array}$ & $\begin{array}{c}6.1 \\
48.5\end{array}$ & $\begin{array}{l}\text { C26, C42a, C42b, and C47 } \\
\text { C1a, C1b, C2, C3a, C3b, C3c, C5, C6, C8, C10, C12, C16, C17, C20, C21a, C21b, } \\
\text { C23, C28, C29, C33, C34a, C34b, C34c, C35, C39, C41a, C41b, C41c, C44, C46a, } \\
\text { C46b, and C46c }\end{array}$ \\
\hline
\end{tabular}

a IBPW = Inquiry-Based Practical Work

b Note: The codes (for example C12 and C34a) in the column, represent specific challenges as seen in Appendix.

the occurrences are in physical sciences and biology education, respectively, with a negligible proportion in physics education settings, as seen towards the top left of the table.

Down the third column in Table 5, we see the codes for the specific challenges associated with each field of natural sciences education. For example, using Appendix, we see that C6, which is reported in research focusing on biology education, says that many teachers did not have the opportunity to experience scientific inquiry, during their prior and teacher education.

\section{Education framework perspective}

The description of the 66 occurrences of the 47 contextual teaching challenges in relation the level of the education framework in which each occurs, is found in Table 6.
As seen in the first two columns in Table 6, the contextual teaching challenges linked to IBPW, occur at the system and school levels. In the system level, the non-material-related challenges are predominant, unlike the case at the school level. We see this in the proportions of the challenges in the third column in the table. The proportions in the fourth column show that the challenges are deeply divided between the system- and the school-level of the framework. In general, the challenges are diverse, from the educational framework perspective.

The codes in last column in Table 6, show which specific challenges lie in the corresponding primary and/or secondary category of the challenges. Reading this column in conjunction with Appendix, allows one to find the specific challenges in each category. Consider, for example, C21a and C21b, in the non-material-related system-level category. The challenge as seen in 
Appendix says that curricula often emphasise learner mastery of content, rather than the enhancement of their investigative skills.

Overall, considering Figure 5, coupled with Tables 4, 5 and 6 , the 47 contextual teaching challenges linked to IBPW that are reported in 66 instances, are considerably diverse, given that they are spread over a number of categories from the perspectives of the geographical location, field of education, level of education, and education framework. The preceding results are all linked to the deductive component in the data analysis. This is unlike the subsequent results, which are the outcomes of the inductive component of the analysis. As explained within the sixth paragraph in section Extracting and Analysing the Data, the subsequent results are solely from the education framework perspective.

\section{Inductively-Generated Description of the Challenges: Education Framework Perspective}

It may be worth recalling that the description of the challenges from the education framework perspective resulting from the deductive data analysis, involved primary and secondary categories of the challenges. Due to the inductive data analysis, we found twelve tertiary categories of the challenges across the different primary and secondary categories. The tertiary categories are listed in the first column in Table 7. The proportion of challenges in each tertiary category is found in the second column in the table.

In Table 7, the proportion of challenges in some tertiary categories is considerably higher. Examples are the Time constraints, Developmental age, and Physical resources tertiary categories. Compared especially to these categories, the proportion of challenges in the Large classes tertiary category is relatively low.

Next, is a presentation of the challenges in each tertiary category in Table 7. This is within the framework of the different primary and secondary categories. It is worth bearing in mind that only the abridged version of most of the challenges are used, with the full version available in Appendix. To link the two versions, we have used superscripts consisting of the codes for each challenge (for example, ${ }^{\mathrm{C}} 26$ and ${ }^{\mathrm{C}} 42 \mathrm{a}$ ), following the statement of the challenge.

\section{System-level: Material-related tertiary categories}

Quality of school texts. While inquiry-based activities are scarce in some school science textbooks (Abd-ElKhalick et al., 2004; Crawford, 2016) C42a, C42b, the activities in manuals for practical work, are usually restricted to structured inquiry (Zion, Cohen, \& Amir, 2007) ${ }^{C 26}$. It has been claimed that finding genuinely open-ended problems that can be investigated in the classroom is difficult (Kind et al., 2011) ${ }^{\mathrm{C} 47}$.
Table 7. Further description of contextual challenges regarding IBPW a from the education framework perspective

\begin{tabular}{lc}
\hline Tertiary category b & $\begin{array}{c}\text { Proportion of } \\
\text { challenges (\%) }\end{array}$ \\
\hline Large classes II, A & 2.1 \\
School culture II, B & 6.4 \\
Quality of school texts I, A & 6.4 \\
Curriculum design I, B & 6.4 \\
Assessment practices I, B & 6.4 \\
Teacher education I, B & 6.4 \\
Classroom and laboratory facilities II, A & 8.5 \\
Learner-related difficulties II, B & 8.5 \\
Teacher support II, B & 8.5 \\
Physical resources II, A & 12.8 \\
Developmental age I, B & 12.8 \\
Time constraints I, B & 14.9 \\
\hline a IBPW = Inquiry-Based Practical Work & \\
b Note: The superscripts in this column, indicate, first, the \\
associated primary category (I or II), then the secondary \\
category (A or B): \\
I = System-level \\
II = School-level \\
A = Material-related \\
B = Non-material-related
\end{tabular}

\section{System-level: Non-material-related tertiary categories}

Curriculum design. A curriculum was found to have only a few broad ideas linked to experiments and process skills (BouJaoude cited in Abd-El-Khalick et al., 2004) C16, while another curriculum requires that only two practical activities be assessed per grade (Dudu \& Vhurumuku, 2012) ${ }^{\mathrm{C} 17}$. In addition, curricula often lack emphasis on the enhancement of the investigative skills of learners (Childs et al., 2012; Dai et al., 2011) C21a and C21b.

Assessment practices. While the skills developed by some learners from carrying out open-ended inquiry are either not assessed or inadequately recognized (Abrahams \& Reis, 2012; Higgins, 2009; Lederman \& Lederman, 2012) C34a, C34b and C34c, due to a high stakes assessment culture, IBPW is being limited to a few verified activities (Toplis \& Allen, 2012) C2. In addition, standardised-assessments often require strategies based on more passive techniques, at the expense of IBPW (Minner et al., 2010) C35.

Time constraints. There is evidence that IBPW requires more time than verification-based practical work (Abrahams \& Reis, 2012; Anderson, 2007; Carlin, 2010) $\mathrm{C} 3 \mathrm{a}, \mathrm{C} 3 \mathrm{~b}$, and $\mathrm{C} 3 \mathrm{c}$. Allowing students with the time they need to develop their inquiry plans can be difficult (Jordan et al., 2011) ${ }^{C 33}$, with inquiry needing time, for example, to design experiments and communicate the findings (Keen-Rocha, 2005) C8. As a result, instructors occasionally avoid inquiry-based activities (Keen-Rocha, 2005) C28, and limit practical work to a small number of verified investigations (Toplis \& Allen, 2012) ${ }^{\mathrm{C} 23}$. Also, some teachers implement the minimum of 'full inquiry' that is required towards the assessment of practical 
investigations (Dai et al., 2011) C10. It has also been found that the integration of inquiry in practical work, affected the duration of the learning programme (Higgins, 2009) C39.

Developmental age. It has been found that reading literature on scientific inquiry, can be difficult for young learners (Baker et al., 2002) C29, and that science questions do not freely arise from learners (Chin \& Osborne, 2008) C12. Also noted is the fact that asking relevant and productive science-related questions is rather difficult, especially for children of preschool age (Bell et al., 2010; Ergazaki \& Zogza, 2013; Marbach-Ad \& Sokolove, 2000) C41a, C41b and C41c, while hypothesis testing is very hard for young people (Klahr, 2000; Kuhn \& Dean, 2005) C1a and C1b. Young children may not have the cognitive resources that adults possess, in relation to designing controlled experiments and evaluating their models (Klahr, 2000; Kuhn \& Dean, 2004; Masnick \& Klahr, 2003) C46a, C46b and C46c. Investigations have been found to often lead to new lines of learner questions that teachers are not ready to pursue, given the young age of the learners (Samarapungavan et al., 2008) C20.

Teacher education. While many teachers did not experience scientific inquiry during their prior and teacher education (Zion et al., 2007) C6, the successful enactment of inquiry-based science projects, tends to require extended professional support (Lederman \& Lederman, 2012) C44. A critical hindrance that some teachers are confronted with in relation to IBPW, is the lack of nationwide teacher professional development (Higgins, 2009) C5.

\section{School-level: Material-related tertiary categories}

Classroom and laboratory facilities. The facilities needed has been noted as an obstacle to classroom inquiry (Baker et al., 2002; Jackson \& Boboc, 2008) C7a and C7b, with some teachers citing limitations in classroom space as a key hindrance associated with IBPW (Kidman, 2012) C14. Also, researchers have found that science laboratories are absent or have limitations, especially in schools in rural settings (Childs et al., 2012; Kriek \& Grayson, 2009; VanBalkom \& Sherman, 2010) C30a, C30b and C30c, as a result of which it is not easy for teachers to have access to science laboratories (Higgins, 2009; Kennedy, 2013) C15a and $\mathrm{C} 15 \mathrm{~b}$.

Large classes. Teachers of a township school interviewed about learners doing inquiry, cited the large classes they teach as a challenge (Ramnarain, 2014) C43. Such classes cause teachers to resort to didactic pedagogy.

Physical resources. Barriers to student inquiry include the materials needed (Jackson \& Boboc, 2008) C31. For example, an attempt to engage several groups of students in the investigation of a lake ecosystem, met with difficulties given the need for multiple sets of technologies (including a digital titrator and veneer sensors) (Ebenezer et al., 2011) ${ }^{\mathrm{C} 19}$. There is a short supply of conventional natural sciences education materials and equipment in many schools (Kapanadze \& Eilks, 2014; Qhobela \& Moru, 2014; Singh \& Singh, 2012) C36a, C36b and C36c, with teachers foreseeing that the lack of physical resources would be a key hindrance when implementing the inquiry component of a new science curriculum (Kidman, 2012) C40. Actually, the unavailability of equipment (e.g., hot plate), limits the investigations that teachers can allow their learners to perform (Capobianco \& Thiel, 2006) ${ }^{C 45}$, in addition to limiting the use of IBPW by some teachers (Ramnarain \& Schuster, 2014) C4.

\section{School-level: Non-material-related tertiary categories}

Learner-related difficulties. In some classrooms, IBPW is seriously constrained by the lack of prior learner experience (Ramnarain \& Schuster, 2014) C38. Although the participation of learners in the formulation of a researchable question is crucial in open inquiry, this type of inquiry depends on the cognitive abilities of learners (Zion \& Mendelovici, 2012) C37, with some learners struggling, for example, to link an inquiry question to the associated phenomenon, design an experiment, handle equipment, and select suitable methods (Zion et al., 2007) C11. Inadequacies in their competencies, constrained some high school learners when conducting full inquiry (Gengarelly \& Abrams, 2009) C13.

Teacher support. In some schools, teachers suffer from inadequate managerial support in relation to IBPW (Huziak-Clark et al., 2007; Ramnarain, 2011) C9a and C9b, or from the absence of laboratory assistants (Higgins, 2009) C18. The lack of valuing and pressure from parents could hinder the use of inquiry-based activities in classroom (Crawford, 2007; Huziak-Clark et al., 2007) C27a and C27b. Also, some teachers have been found to face the lack of valuing of inquiry-based activities, by their colleagues (Huziak-Clark et al., 2007) C25.

School culture. School context is another factor that could inhibit success in teaching science as inquiry (Crawford, 2007) C32. School ethos which is significantly constraining the use of IBPW by some teachers (Ramnarain \& Schuster, 2014) ${ }^{\mathrm{C} 24}$, can take the form of the lack of learner motivation and inadequate prior experience (Gengarelly \& Abrams, 2009) C22.

\section{DISCUSSION AND CONCLUSIONS}

Recall that the goal of the systematic review presented in this paper, was to gather the contextual teaching challenges relating to IBPW, that occur in a dispersed manner, in the international school and postschool natural sciences education research literature, and to then create a detailed multi-perspective description of challenges. The 47 challenges with 66 reported occurrences that we found, fall in multiple categories from the perspective of the geographical location, level of education, field of natural sciences 
education, and educational framework level (Figure 5, and Tables $4-6$, respectively). Thus, the challenges are many in number and occurrences, in addition to being diverse considering the four different perspectives.

\section{Contribution}

Descriptions of contextual teaching challenges linked to IBPW such as the current study, are rare in the international research literature about school and postschool natural sciences education. The only readily available description appears to be one from a case study of physical science classrooms in two non-fee-paying South African schools (Akuma \& Callaghan, 2019). The case study describes the contextual teaching challenges linked to IBPW from the education framework perspective only. From this perspective, however, there are differences between the existing description (Akuma \& Callaghan) and the current one. For example, there are eight tertiary categories of the challenges in the existing description, unlike in the current results where there are twelve. The number of newly identified tertiary categories is seven and consist of Quality of school texts, Assessment practices, Developmental age, Teacher education, Large classes, Teacher support, and School culture. Although this is a significant addition to our knowledge about the teaching challenges, even more striking, is the fact that the current results provide a description of the contextual teaching challenges associated with IBPW, from three perspectives that have not been used before in describing the challenges. The new perspectives which significantly improve the existing description of these challenges, are the level of education, field of natural sciences education, and geographical location (section Deductively-Generated Description of the Challenges).

Overall, the current description of contextual teaching challenges associated with IBPW adds new perspectives and detail to the existing description of the challenges. When a phenomenon is described in detail, this helps in uncovering the complex nature of the phenomenon (Rozenszajn \& Yarden, 2014). The description of contextual teaching challenges associated with IBPW achieved in this study, presents our response to calls for a detailed picture of teaching challenges. Although the calls are, for example, in relation to practical work (Nivalainen et al., 2010) and the incorporation of inquiry-based strategies in natural sciences education (Crawford, 2007), we address the intersection of these two domains in the current research, and in terms of contextual teaching challenges linked to IBPW. In this regard, the results also show that contextual teaching challenges relating to IBPW, cut across levels of the education framework, levels of education, and fields of natural sciences education, while being scattered in locations across continents.
At a broader level, the current results make another contribution. This is in the sense that they complement existing descriptions of teacher-based teaching challenges associated with IBPW (Akuma \& Callaghan, 2018), allowing for a more holistic understanding of the teaching challenges associated with IBPW.

\section{Implications}

The presented results have research-, and practicebased implications. Regarding the practice-based implications, it has been noted that the successful implementation of science education reforms in general, and in inquiry-based science education, requires extended teacher support, even in the case of experienced teachers (Lederman \& Lederman, 2012; National Research Council, 2015). It has been noted that to provide teachers the support they need, it is necessary to have an understanding of the difficulties that they face (Harris \& Rooks, 2010). The presented results inform understanding regarding challenges relating to IBPW, along four perspectives: level of education, field of natural sciences education, geographical location, and education framework.

Independent of the perspective, the results seem to suggest that there is the need for more teacher support in relation to specific categories, considering the relative proportions of the challenges. The most attention appears to be needed, for example, in North America (Figure 5), in the Upper secondary education and Postsecondary education levels (Table 4); and in Integrated natural sciences education settings (Table 5). From the education framework perspective, the system-level nonmaterial related category, appears to need the most attention (Table 6). In this secondary category, the specific tertiary categories seeming to need more attention are the Time constraints category and the Developmental age categories (Table 7). While suggesting categories that may need more attention when providing teachers support, the results allow for a focus on specific challenges, as a function of the given geographical location, level of education, field of natural sciences education, and education framework level. In this regard, Figure 5, and Tables $4-6$, respectively, provide codes for the specific applicable challenges, as decoded in the first two columns in Appendix. In the specific case of the education framework perspective (Tables 6 and 7), the applicable challenges can also be found using section Inductively-Generated Description of the Challenges: Education Framework Perspective, where the codes appear as superscripts in the end of statements of the corresponding challenges.

For actually providing teachers support in relation to each of the many and diverse challenges identified, there may be the need for a systematic search of the research literature in terms of identifying possible strategies. Taking the Time constraints category as an example, a 
possible strategy seen in National Research Council (2005b), is block-scheduling, wherein time could be freed in the school timetable for inquiry. On this basis, instead of classes taking place every day for 40 or 45 minutes, they come together after each other day, during longer periods of about 90-100 minutes. However, this strategy is not necessarily applicable everywhere, thus the need to identify other possible strategies. Another researchrelated implication lies in the relatively large differences in the proportion of challenges in the different categories under each of the four perspectives used in the analyses. Examples are Africa and North America (Figure 5); Primary and Upper secondary education (Table 4); coupled with Biology and Integrated natural sciences (Table 5). In this regard, one question that arises is whether some categories of the challenges are under researched. A third research-related implication of the current results, is linked to the fact noted by Rozenszajn and Yarden (2014), that a detailed description of any phenomenon (in this case the contextual teaching challenges associated with IBPW), assists in tracking the evolution of the phenomenon. This suggests that the description of the challenges reflected in Figure 5, and in Tables $4-7$, could be used in longitudinal studies on the evolution of contextual teaching challenges linked to IBPW. It has been noted that by identifying the discrete categories of a concept, researchers can better create data collection instruments to arrive at knowledge about specific categories (Abell, 2008). Thus, as the fourth research-related implication this systematic review, researchers are encouraged to zoom into, for example, the different tertiary categories of the challenges shown in Table 7.

\section{CONCLUSION}

The presented systematic review, significantly increases knowledge about the complexity of the contextual teaching challenges relating to IBPW, that occur in school and post-school natural sciences education settings. This is with the introduction of three new perspectives in the description of the challenges, coupled with more and new categories, considering the previously reported description from the education framework perspective. The challenges occur mostly in the northern hemisphere, with the highest proportion occurring in the Upper secondary and Post-secondary education levels. In addition, more than half of the challenges occur in integrated natural sciences education settings, while being deeply divided between the system- and the school-levels of the education framework.

The existence of these challenges, which appear systemic from the different perspectives, coincides with the predominance of verification-based practical work in natural sciences education settings in many countries around the world. While there is value in this type of practical work, its dominance is not surprising, given the many and diverse contextual challenges associated with IBPW as seen in this systematic review. Contextual challenges relating to IBPW, are definitely limiting the implementation of practical work that critically engages learners towards the development of scientific practices.

The research results allow for a systemic and a sectorwise approach, when supporting teachers in the implementation of IBPW. The results also suggest possible lines in future research towards better supporting teachers and further unravelling the contextual challenges associated with IBPW. The thus informed future efforts of researchers and teacher support providers, should contribute towards greater use of practical work that focuses on critical learner engagement in the development of scientific practices and the understanding of scientific inquiry.

Author contributions: All authors have sufficiently contributed to the study, and agreed with the results and conclusions.

Funding: No funding source is reported for this study.

Declaration of interest: No conflict of interest is declared by authors.

\section{REFERENCES}

Abd-El-Khalick, F., BouJaoude, S., Duschl, R., Lederman, N. G., Mamlok-Naaman, R., Hofstein, A., Niaz, M., Treagust, D., \& Tuan, H. (2004). Inquiry in science education: International perspectives. Science Education, 88(3), 397-419. https:/ / doi.org/10.1002/ sce.10118

Abelha, M., Fernandes, S., Mesquita, D., Seabra, F., \& Ferreira-Oliveira, A. T. (2020). Graduate employability and competence development in higher education - a systematic literature review using PRISMA. Sustainability, 12(15), 5900. https:/ / doi.org/10.3390/su12155900

Abell, S. K. (2008). Twenty years later: Does pedagogic content knowledge remain a useful idea? International Journal of Science Education, 30(10), 1405-1416. https:/ / doi.org/10.1080/09500690802187041

Abrahams, I., \& Millar, R. (2008). Does practical work really work? A study of the effectiveness of practical work as a teaching and learning method in school science. International Journal of Science Education, 30(14), 1945-1969. https://doi.org/ 10.1080/09500690701749305

Abrahams, I., \& Reis, M. J. (2012). Practical work: Its effectiveness in primary and secondary schools in England. Journal of Research in Science Teaching, 49(8), 1035-1055. https://doi.org/10.1002/ tea. 21036

Abrams, E., Southerland, S. A., \& Evans, C. A. (2007). Inquiry in the classroom: Necessary components of a useful definition. In E. Abrams, S. A. Southerland, \& P. Silva (Eds.), Inquiry in the science classroom: 
Realities and opportunities. Information Age Publishing.

Afra, N. C., Osta, I., \& Zoubeir, W. (2009). Students' alternative conceptions about electricity and effect of inquiry-based teaching strategies. International Journal of Science and Mathematics Education, 7(1), 103-132. https://doi.org/10.1007/s10763-0079106-7

Aksela, M., \& Boström, M. (2012). Supporting students' interest through inquiry-based learning in the context of fuel cells. Mevlana International Journal of Education, 2(3), 53-61.

Akuma, F. V., \& Callaghan, R. (2018). A systematic review characterising and clarifying intrinsic teaching challenges linked to inquiry-based practical work. Journal of Research in Science Teaching, 56(5), 619-648. https://doi.org/10.1002/ tea. 21516

Akuma, F. V., \& Callaghan, R. (2019). Characterising extrinsic challenges linked to the design and implementation of inquiry-based practical work. Research in Science Education, 49(6), 1677-1706. https:// doi.org/10.1007/s11165-017-9671-x

Alexakos, K. (2010). Teaching the practice of science, unteaching the "scientific method". Science Scope, 33(9), 74-79.

Anderson, R. D. (2007). Inquiry as an organizing theme for science curricula. In K. S. Abell \& N. G. Lederman (Eds.), Handbook of research on science education (pp. 807-830). Routledge.

Baker, W. P., Lang, M., \& Lawson, A. E. (2002). Classroom management for successful student inquiry. The Clearing House 75(5), 248-252. https:/ / doi.org/10.1080/00098650209603949

Bartos, S. A., \& Lederman, N. G. (2014). Teachers' knowledge structures for nature of science and scientific inquiry: Conceptions and classroom practice. Journal of Research in Science Teaching, 51(9), 1150-1184. https:// doi.org/10.1002/tea.21168

Bell, T., Urhahne, D., Schanze, S., \& Ploetzner, R. (2010). Collaborative inquiry learning: Models, tools, and challenges. International Journal of Science Education, 32(3), 349-377. https:// doi.org/10.1080/095006 90802582241

Blanchard, M. R., Southerland, S. A., Osborne, J. W., Sampson, V. D., Annetta, L. A., \& Granger, E. M. (2010). Is inquiry possible in light of accountability?: A quantitative comparison of the relative effectiveness of guided inquiry and verification laboratory instruction. Science Education, 94, 577-616. https://doi.org/10.1002/ sce. 20390

Boldrini, E., Sappa, V., \& Aprea, C. (2019). Which difficulties and resources do vocational teachers perceive? An exploratory study setting the stage for investigating teachers' resilience in Switzerland. Teachers and Teaching, 25(1), 125-141. https:/ / doi.org/10.1080/13540602.2018.1520086

Bowen, R. S., Picard, D. R., Verberne-Sutton, S., \& Brame, C. J. (2018). Incorporating student design in an HPLC lab activity promotes student metacognition and argumentation. Journal of Chemical Education, 95, 108-115. https://doi.org/10.1021/ acs.jchemed.7b00258

Boyatzis, R. (1998). Transforming qualitative information: Thematic analysis and code development. Sage.

Bybee, R. (2000). Teaching science as inquiry. In J. Minstrell \& E. H. van Zee (Eds.), Inquiring into inquiry learning and teaching in science (pp. 20-46). American Association for the Advancement of Science.

Capobianco, B., \& Thiel, E. A. (2006). Are you UV safe? Science and Children, 44(1), 26-31.

Carlin, J. L. (2010). An investigative alternative to singlespecies dissection in the introductory biology laboratory. Bioscene, 36(2), 28-33.

Chairam, S., Klahan, N., \& Coll, R. (2015). Exploring secondary students' understanding of chemical kinetics through inquiry-based learning activities. Eurasia Journal of Mathematics, Science and Technology Education, 11(5), 937-956. https:/ / doi.org/10.12973/eurasia.2015.1365a

Childs, A., Tenzin, W., Johnson, D., \& Ramachandran, K. (2012). Science education in Bhutan: Issues and challenges. International Journal of Science Education, 34(3), 375-400. https://doi.org/10.1080/ 09500693.2011.626461

Chin, C., \& Osborne, J. (2008). Students' questions: A potential resource for teaching and learning science. Studies in Science Education, 44(1), 1-39. https:// doi.org/10.1080/03057260701828101

Clarke, D., \& Hollingsworth, H. (2002). Elaborating a model of teacher professional growth. Teaching and Teacher Education, 18(8), 947-967. https:/ / doi.org/10.1016/S0742-051X(02)00053-7

Corlu, M. A., \& Aydin, E. (2016). Evaluation of learning gains through integrated STEM projects. International Journal of Education in Mathematics, Science and Technology, 4(1), 20-29. https:/ / doi.org/10.18404/ijemst.35021

Crabtree, B., \& Miller, W. (1999). A template approach to text analysis: Developing and using codebooks. In B. Crabtree \& W. Miller (Eds.), Doing qualitative research (pp. 163-177). Sage.

Crawford, B. A. (2007). Learning to teach science as inquiry in the rough and tumble of practice. Journal of Research in Science Teaching, 44(4), 613-642. https:// doi.org/10.1002/tea.20157 
Crawford, B. A. (2016). Supporting teachers in inquiry/science practices, modeling, and complex reasoning in science classrooms [Paper presentation]. Southern Africa Association of Maths, Science, and Technology Education Annual Conference, South Africa, Pretoria.

Dai, D. Y., Gerbino, K. A., \& Daley, M. J. (2011). Inquirybased learning in China: Do teachers practice what they preach, and why? Frontiers of Education in China, 6(1), 139-157. https://doi.org/10.1007/ s11516-011-0125-3

Department of Basic Education. (2011). Curriculum and assessment policy statement Grades 10-12 Physical sciences. Government Printing Works.

Di Biase, R. (2019). Moving beyond the teachercentred/learner-centred dichotomy: implementing a structured model of active learning in the Maldives. Compare: A Journal of Comparative and International Education, 49(4), 565-583.

Di Fuccia, D., Witteck, T., Markic, S., \& Eilks, I. (2012). Trends in practical work in German science education. Eurasia Journal of Mathematics, Science $\mathcal{E}$ Technology Education, 8(1), 59-72. https://doi.org/ 10.12973/eurasia.2012.817a

Duangpummet, P., Chaiyen, P., \& Chenprakhon, P. (2019). Lipase-catalyzed esterification: An inquirybased laboratory activity to promote high school students' understanding and positive perceptions of green chemistry. Journal of Chemical Education, 96, 1205-1211. https://doi.org/10.1021/acs.jchemed. $8 \mathrm{~b} 00855$

Dudu, W. T., \& Vhurumuku, E. (2012). Teachers' practices of inquiry when teaching investigations: A case study. Journal of Science Teacher Education, 3, 579-600.

Ebenezer, J., Kaya, O. N., \& Ebenezer, D. L. (2011). Engaging students in environmental research projects: Perceptions of fluency with innovative technologies and levels of scientific inquiry abilities. Journal of Research in Science Teaching, 48, 94-116. https:/ / doi.org/10.1002/tea.20387

Elmore, R. F. (1996). Getting to scale with good educational practice. Harvard Educational Review, 66(1), 1-26. https://doi.org/10.17763/haer.66.1. g73266758j348t33

Ergazaki, M., \& Zogza, V. (2013). How does the model of inquiry-based science education work in the kindergarten: The case of biology. Review of Science, Mathematics and ICT Education, 7(2), 73-97.

ET 2020 Working Group on Schools. (2018). Teachers and school leaders in schools as learning organisations. European Commission. https://connections.etf. europa.eu/files/form/anonymous/api/library/4 4b84057-e0b1-47f6-92cc-0e58d0b305ce/document/ 36b6a4bd-89f0-4ba9-9af3-bdd464812cc9/media/
WGS-int-rep-Teachers-and-school-leaders-Sep2017.pdf

Gengarelly, L. M., \& Abrams, E. D. (2009). Closing the gap: Inquiry in research and the secondary science classroom. Journal of Science Education and Technology, 18, 74-84. https://doi.org/10.1007/ s10956-008-9134-2

Harris, C. J., \& Rooks, D. L. (2010). Managing inquirybased science: Challenges in enacting complex science instruction in elementary and middle school classrooms. Journal of Science Teacher Education, 21, 227-240. https://doi.org/10.1007/ s10972-009-9172-5

Henderson, C., Beach, A., \& Finkelstein, N. (2011). Facilitating change in undergraduate STEM instructional practices: An analytic review of the literature. Journal of Research in Science Teaching, 48(8), 952-984. https:/ / doi.org/10.1002/tea.20439

Heradio, R., Chacon, J., Vargas, H., Galan, D., Saenz, J., De La Torre, L., \& Dormido, S. (2018). Open-source hardware in education: A systematic mapping study. IEEE Access, 6, 72094-72103. https:/ / doi.org/10.1109/ACCESS.2018.2881929

Herron, M. D. (1971). The nature of scientific enquiry. School Review, 79, 171-212. https:/ / doi.org/10.1086/442968

Higgins. (2009). ISTA questionnaire on junior certificate science. Science, 45(1), 17-19.

Hodson, D. (2014). Learning science, learning about science, doing science: Different goals demand different learning methods. International Journal of Science Education, 36(15), 2534-2553. https:/ / doi.org/10.1080/09500693.2014.899722

Hofstein, A., \& Lunetta, V. N. (2004). The laboratory in science education: Foundations for the twenty-first century. Science Education, 88(1), 28-54. https:/ / doi.org/10.1002/sce.10106

Huziak-Clark, T., Van Hook, S. J., Nurnberger-Haag, J., \& Ballone-Duran, L. (2007). Using inquiry to improve pedagogy through K-12/university partnerships. School Science and Mathematics, 107(8), 311-324. https://doi.org/10.1111/j.19498594.2007.tb17796.x

Jackson, D. K., \& Boboc, M. (2008). Facilitating an inquiry-based science classroom. Science Scope, 31(5), 64-67.

Jagodziński, P., \& Wolski, R. (2015). Assessment of application technology of natural user interfaces in the creation of a virtual chemical laboratory. Journal of Science Education and Technology, 24(1), 16-28. https:/ / doi.org/10.1007/s10956-014-9517-5

Jones, A. (2004). A review of the research literature on barriers to uptake of ICT by teachers. British Educational Communications and Technology Agency. www.becta.org.uk 
Jordan, R. C., Ruibal-Villasenor, M., Hmelo-Silver, C. E., \& Etkina, E. (2011). Laboratory materials: Affordances or constraints? Journal of Research in Science Teaching, 48(9), 1010-1025. https:/ / doi.org/ 10.1002/ tea.20418

Kapanadze, M., \& Eilks, I. (2014). Supporting reform in science education in central and eastern Europe Reflections and perspectives from the project TEMPUS-SALiS. Eurasia Journal of Mathematics, Science $\mathcal{E}$ Technology Education, 10(1), 47-58. https:// doi.org/10.12973/eurasia.2014.1016a

Keen-Rocha, L. (2005). To tan or not to tan? Science Teacher, 72(6), 46-50.

Kennedy, D. (2013). The role of investigations in promoting inquiry-based science education in Ireland. Science Education International, 24(3), 282305.

Khan, S. (2011). New pedagogies on teaching science with computer simulations. Journal of Science Education and Technology, 20(3), 215-232. https:/ / doi.org/10.1007/s10956-010-9247-2

Kidman, G. (2012). Australia at the crossroads: A review of school science practical work. Eurasia Journal of Mathematics, Science and Technology Education, 8(1), 35-47. https:/ / doi.org/10.12973/eurasia.2012.815a

Kim, M., \& Tan, A. 1. (2010). Rethinking difficulties of teaching inquiry-based practical work: Stories from elementary pre-service teachers. International Journal of Science Education, 33(4), 465-486. https:/ / doi.org/10.1080/09500691003639913

Kind, P. M., Kind, V., Hofstein, A., \& Wilson, J. (2011). Peer argumentation in the school science laboratory: Exploring effects of task features. International Journal of Science Education, 33(18), 2527-2558.

https:/ / doi.org/10.1080/09500693.2010.550952

Klahr, D. (2000). Exploring science: The cognition and development of discovery processes. MIT Press.

Kriek, J., \& Grayson, D. (2009). A holistic professional development model for South African physical science teachers. South African Journal of Education, 29, 185-203. https://doi.org/10.15700/saje. v29n2a123

Kuhn, D., \& Dean, D. (2004). Connecting scientific reasoning and causal inference. Journal of Cognition and Development, 5(2), 261-288. https:/ / doi.org/10.1207/s15327647jcd0502_5

Kuhn, D., \& Dean, D. (2005). Is developing scientific thinking all about learning to control variables? Psychological Science, 16(11), 866-870. https:/ / doi.org/10.1111/j.1467-9280.2005.01628.x

Lavonen, J., \& Laaksonen, S. (2009). Context of teaching and learning school science in Finland: Reflections on PISA 2006 results. Journal of Research in Science
Teaching, 46(8), 922-944. https://doi.org/10.1002/ tea.20339

Lederman, N. G., \& Lederman, J. S. (2012). Nature of scientific knowledge and scientific inquiry: Instructional capacity through professional development. In B. J. Fraser, K. Tobin, \& C. J. McRobbie (Eds.), Second international handbook of science education (pp. 335-359). Springer. https:/ / doi.org/10.1007/978-1-4020-9041-7_24

Lunetta, V. N. (1998). The school science laboratory: Historical perspectives and contexts for contemporary teaching. In B. J. Fraser \& K. G. Tobin (Eds.), International handbook of science education (pp. 249-264). Kluwer Academic Publishers. https:/ / doi.org/10.1007/978-94-011-4940-2_16

Maeng, J., \& Bell, R. (2013). Theories, laws, and hypotheses. The Science Teacher, 80(7), 38-43. https: / / search.proquest.com/ docview / 146056741 4? fromopenview $=$ true\&pq-origsite $=$ gscholar

Makoelle, T. M. (2012). The state of inclusive pedagogy in South Africa: A literature review. Journal of Sociology and Social Anthropology, 3(2), 93-102. https: / / doi.org/10.1080/09766634.2012.11885569

Marbach-Ad, G., \& Sokolove, P. G. (2000). Can undergraduate biology students learn to ask higher level questions? Journal of Research in Science Teaching, 37(8), 854-870. https://doi.org/10.1002/ 1098-2736(200010)37:8<854::AID-TEA6>3.0.CO;2-5

Martin, J. P., Choe, N. H., Halter, J., Foster, M., Froyd, J., Borrego, M., \& Winterer, E. R. (2019). Interventions supporting baccalaureate achievement of Latinx STEM students matriculating at 2-year institutions: A systematic review. Journal of Research in Science Teaching, 56(4), 440-464. https://doi.org/10.1002/ tea. 21485

Masnick, A. M., \& Klahr, D. (2003). Error matters: An initial exploration of elementary school children's understanding of experimental error. Journal of Cognition and Cognitive Development, 4(1), 67-98. https:/ / doi.org/10.1080/15248372.2003.9669683

Millar, R. (2009). Analysing practical activities to assess and improve effectiveness: The Practical Activity Analysis Inventory (PAAI). Centre for Innovation and Research in Science Education, University of York. http://www.york.ac.uk/depts/educ/research/R esearchPaperSeries/index.htm

Minner, D., Levy, A., \& Century, J. (2010). Inquiry-based science instruction - What is it and does it matter? Results from a research synthesis years 1984 to 2002. Journal of Research in Science Teaching, 47(4), 474-496. https:/ / doi.org/10.1002/ tea.20347

National Council for Curriculum and Assessment. (2008). Junior Certificate Science Syllabus: Ordinary Level and Higher Level. Dublin 2. https://www. education.ie/en/Schools-Colleges/Information/ 
Curriculum-and-Syllabus/Junior-Cycle-

/Syllabuses-Guidelines/jc_science_sy_rev.pdf

National Research Council. (2000). Inquiry and the national science education standards: A guide to teaching and learning. National Academy Press.

National Research Council. (2005a). America's lab report: Investigations in high school science. National Academy Press.

National Research Council. (2005b). How students learn science in the classroom. National Academy Press.

National Research Council. (2006). America's lab report: Investigations in high school science. National Academy Press.

National Research Council. (2007). Taking science to school: Learning and teaching science in grades $\mathrm{K}-8$. National Academies Press.

National Research Council. (2012). A framework for K-12 science education: Practices, crosscutting concepts, and core ideas. The National Academies Press. https:/ / smile.oregonstate.edu/sites/smile.oregon state.edu/files/a_framework_for_k-

12_science_education.pdf

National Research Council. (2015). Guide to implementing the next generation science standards. Committee on Guidance on Implementing the Next Generation Science Standards. Board on Science Education, Division of Behavioral and Social Sciences and Education: The National Academies Press.

National Science Teaching Association. (2018). Transitioning from scientific inquiry to threedimensional teaching and learning. https: / www.nsta .org/nstas-official-positions/transitioningscientific-inquiry-three-dimensional-teaching-andlearning

Nedungadi, P., Malini, P., \& Raman, R. (2015). Inquiry based learning pedagogy for chemistry practical experiments using OLabs. In Advances in intelligent informatics (pp. 633-642). Springer. https: / / doi.org/10.1007/978-3-319-11218-3_56

Nivalainen, V., Asikainen, M. A., Sormunen, K., \& Hirvonen, P. E. (2010). Preservice and inservice teachers' challenges in the planning of practical work in physics. Journal of Science Teacher Education, 21(4), 393-409. https://doi.org/10.1007/s10972010-9186-Z

Page, M. J., McKenzie, J. E., Bossuyt, P. M., Boutron, I., Hoffmann, T. C., Mulrow, C. D., Shamseer, L., Tetzlaff, J. M., Akl, E. A., Brennan, S. E., Chou, R., Glanville, J., Grimshaw, J. M., Hróbjartsson, A., Lalu, M. M., Li, T., Loder, E. W., Mayo-Wilson, E., McDonald, S., ... Moher, D. (2021). The PRISMA 2020 statement: An updated guideline for reporting systematic reviews. BMJ, 372, n71. https:/ / doi.org/10.1136/bmj.n71
Park, M., \& Liu, X. (2016). Assessing understanding of the energy concept in different science disciplines. Science Education, 100(3), 483-516. https:// doi.org/10.1002/sce.21211

Pelgrum, W. J. (2001). Obstacles to the integration of ICT in education: Results of a worldwide educational assessment. Computers E Education, 37, 163-178. https://doi.org/10.1016/S0360-1315(01)00045-8

Petticrew, M., \& Roberts, H. (2006). Systematic reviews in the social sciences: A practical guide. Blackwell Publishing. https:/ / doi.org/10.1002/9780470754887

Plomp, T., \& Nieveen, N. (2013). Educational design research Part B: Illustrative cases. Netherlands Institute for Curriculum Development.

Qhobela, M., \& Moru, E. K. (2014). Understanding challenges physics teachers come across as they implement learner-centred approaches in Lesotho. African Journal of Research in Mathematics, Science and Technology Education, 18(1), 63-74. https:/ / doi.org/10.1080/10288457.2014.884351

Ramnarain, U. D. (2011). Equity in science at South African schools: A pious platitude or an achievable goal? International Journal of Science Education, 33(10), 1353-1371. https://doi.org/10.1080/ 09500693.2010 .510855

Ramnarain, U. D. (2014). Teachers' perceptions of inquiry-based learning in urban, suburban, township and rural high schools: The contextspecificity of science curriculum implementation in South Africa. Teaching and Teacher Education, 38, 6575. https:/ / doi.org/10.1016/j.tate.2013.11.003

Ramnarain, U. D. (2016). Understanding the influence of intrinsic and extrinsic factors on inquiry-based science education at township schools in South Africa. Journal of Research in Science Teaching, 53(4), 598-619. https:/ / doi.org/10.1002/tea.21315

Ramnarain, U. D., \& Schuster, D. (2014). The pedagogical orientations of South African physical sciences teachers towards inquiry or direct instructional approaches. Research in Science Education, 44, 627650. https:/ / doi.org/10.1007/s11165-013-9395-5

Rönnebeck, S., Bernholt, S., \& Ropohl, M. (2016). Searching for a common ground - A literature review of empirical research on scientific inquiry activities. Studies in Science Education, 52(2), 161-197. https:/ / doi.org/10.1080/03057267.2016.1206351

Rozenszajn, R., \& Yarden, A. (2014). Expansion of biology teachers' pedagogical content knowledge (PCK) during a long-term professional development program. Research in Science Education, 44, 189-213. https://doi.org/10.1007/ s11165-013-9378-6

Rutten, N., van Joolingen, W. R., \& van der Veen, J. T. (2012). The learning effects of computer simulations 
in science education. Computers $\mathcal{E}$ Education, 58, 136-153. https:// doi.org/10.1016/j.compedu.2011. 07.017

Sadeh, I., \& Zion, M. (2012). Which type of inquiry project do high school biology students prefer: Open or guided? Research in Science Education, 42, 831-848. https://doi.org/10.1007/s11165-0119222-9

Samarapungavan, A., Mantzicopoulos, P., \& Patrick, H. (2008). Learning science through inquiry in kindergarten. Science Education, 92(5), 868-908. https://doi.org/10.1002/sce.20275

Sandoval, W. A., Kawasaki, J., Cournoyer, N., \& Rodriguez, L. (2016). Secondary teachers' emergent understanding of teaching science practices [Paper presentation]. Transforming learning, empowering learners: The international conference of the learning sciences (ICLS) 2016 (Vol. 2, pp. 737-744).

Schoepp, K. (2005). Barriers to technology integration in a technology-rich environment. Learning and Teaching in Higher Education: Gulf Perspectives, 2(1), 1-24. https:/ / doi.org/10.18538/lthe.v2.n1.02

Schwab, J. J. (1962). The teaching of science as enquiry. In J. J. Schwab \& P. F. Brandwein (Eds.), The teaching of science (pp. 3-103). Harvard University Press.

Sesen, B. A., \& Tarhan, L. (2013). Inquiry-based laboratory activities in electrochemistry: High school students' achievements and attitudes. Research in Science Educution, 43, 413-435. https:/ / doi.org/10.1007/s11165-011-9275-9

Singh, S. K., \& Singh, R. J. (2012). Pre-service teachers' reflections of South African science classrooms. South African Journal of Higher Education, 26(1), 168180. https:/ / doi.org/10.20853/26-1-157

So, W. W.-M. (2013). Connecting mathematics in primary science inquiry projects. International Journal of Science and Mathematics Education, 11(2), 385-406. https://doi.org/10.1007/s10763-0129342-3

Strauss, A., \& Corbin, J. (1990). Basics of qualitative research: Grounded theory procedures and techniques. Sage Publications.
Talanquer, V., Bolger, M., \& Tomanek, D. (2015). Exploring prospective teachers' assessment practices: Noticing and interpreting student understanding in the assessment of written work. Journal of Research in Science Teaching, 52(5), 585-609. https:/ / doi.org/10.1002/tea.21209

Tichnor-Wagner, A., Taguma, M., \& Barrera, M. (2019). OECD Future of Education and Skills 2030: Curriculum analysis. Organisation for Economic Cooperation and Development. https://www.oecd. org/education/2030-project/contact/Change_ management_for_curriculum_implementation_Fa cilitating_and_hindering_factors_of_curriculum_i mplementation.pdf

Toplis, R., \& Allen, M. (2012). 'I do and I understand?' Practical work and laboratory use in United Kingdom schools. Eurasia Journal of Mathematics, Science and Technology Education, 8(1), 3-9. https:/ / doi.org/10.12973/eurasia.2012.812a

UNESCO Institute of Statistics. (2020). ISCED Mappings: UNESCO. http://uis.unesco.org/en/iscedmappings

UNESCO. (2014). ISCED Fields of Education and Training 2013 (ISCED-F 2013). UNESCO-UIS. http://uis. unesco.org/sites/default/files/documents/iscedfields-of-education-and-training-2013-en.pdf

VanBalkom, W. B., \& Sherman, A. (2010). Teacher education in Bhutan: Highlights and challenges for reform. Asia Pacific Journal of Education, 30(1), 43-55. https:// doi.org/10.1080/02188790903503585

Zion, M., \& Mendelovici, R. (2012). Moving from structured to open inquiry: Challenges and limits. Science Education International, 23(4), 383-399.

Zion, M., Cohen, S., \& Amir, R. (2007). The spectrum of dynamic inquiry teaching practices. Research in Science Education, 37(4), 423-447. https:// doi.org/10.1007/s11165-006-9034-5

Zuiker, S., \& Whitaker, J. R. (2014). Refining inquiry with multi-form assessment: Formative and summative assessment functions for flexible inquiry. International Journal of Science Education, 36(6), 10371059. https:// doi.org/10.1080/09500693.2013. 834489 


\section{APPENDIX}

\section{Inventory and Coding Sheet for the Contextual Challenges}

\begin{tabular}{|c|c|c|c|c|c|}
\hline \multicolumn{2}{|c|}{ Challenge } & \multicolumn{4}{|c|}{ Description perspective } \\
\hline Code & Statement of challenge, with citation to associated paper & $\begin{array}{l}\text { Geographical } \\
\text { location a }\end{array}$ & $\begin{array}{c}\text { Education } \\
\text { framework }\end{array}$ & $\begin{array}{c}\text { Level of } \\
\text { education }{ }^{c}\end{array}$ & $\begin{array}{c}\text { Field of } \\
\text { education }{ }^{d}\end{array}$ \\
\hline$\overline{\mathrm{C} 1 \mathrm{a}}$ & \multirow{2}{*}{$\begin{array}{l}\text { Developmental research has suggested that hypothesis testing is a concept that is } \\
\text { very hard for young people to acquire (Klahr, 2000; Kuhn \& Dean, 2005) }{ }^{\mathrm{Cla}, \mathrm{Clb}} \text {. }\end{array}$} & $\mathrm{N} / \mathrm{A}^{\mathrm{e}}$ & $\mathrm{I}, \mathrm{B}, \mathrm{e}$ & $\mathrm{N} / \mathrm{A}$ & $\mathrm{N} / \mathrm{A}$ \\
\hline $\mathrm{C} 1 \mathrm{~b}$ & & $\mathrm{NA}^{\mathrm{f}}$ & $\mathrm{I}, \mathrm{B}, \mathrm{e}$ & 1 & 05 \\
\hline$\overline{\mathrm{C} 2}$ & $\begin{array}{l}\text { Due to a high stakes assessment culture, IBPW is being limited to a few verified } \\
\text { investigative activities that are disconnected from routine science instruction } \\
\text { (Toplis \& Allen, 2012). }\end{array}$ & EU & $\mathrm{I}, \mathrm{B}, \mathrm{b}$ & $2-3$ & 05 \\
\hline$\overline{\mathrm{C} 3 \mathrm{a}}$ & \multirow{3}{*}{$\begin{array}{l}\text { There are concerns, claims and findings to the effect that the enactment of IBPW } \\
\text { requires more time in relation to traditional practical work (Abrahams \& Reis, 2012; } \\
\text { Anderson, 2007; Carlin, 2010) C3a, С3b, С3c. }\end{array}$} & EU & $\mathrm{I}, \mathrm{B}, \mathrm{d}$ & $1-2$ & 05 \\
\hline$\overline{\mathrm{C} 3 \mathrm{~b}}$ & & $\mathrm{~N} / \mathrm{A}$ & $\mathrm{I}, \mathrm{B}, \mathrm{d}$ & $\mathrm{N} / \mathrm{A}$ & $\mathrm{N} / \mathrm{A}$ \\
\hline$\overline{\mathrm{C} 3 \mathrm{c}}$ & & NA & $\mathrm{I}, \mathrm{B}, \mathrm{d}$ & $4-6$ & 0511 \\
\hline$\overline{C 4}$ & $\begin{array}{l}\text { The lack of science education equipment is also constraining some teachers from } \\
\text { using an inquiry-based strategy in practical work (Ramnarain \& Schuster, 2014). }\end{array}$ & $\mathrm{AF}$ & II, A, i & 3 & 053 \\
\hline$\overline{\mathrm{C} 5}$ & $\begin{array}{l}\text { A critical hindrance some teachers are confronted with in relation to IBPW, is the } \\
\text { lack of nationwide teacher professional development to assist them implement an } \\
\text { inquiry-based strategy in practical work (Higgins, 2009). }\end{array}$ & EU & $\mathrm{I}, \mathrm{B}, \mathrm{f}$ & 2 & 05 \\
\hline$\overline{\mathrm{C} 6}$ & $\begin{array}{l}\text { Many teachers did not have the opportunity to experience scientific inquiry, during } \\
\text { their prior and teacher education (Zion, Cohen, \& Amir, 2007). }\end{array}$ & AS & $\mathrm{I}, \mathrm{B}, \mathrm{f}$ & 3 & 0511 \\
\hline $\mathrm{C7a}$ & \multirow{2}{*}{$\begin{array}{l}\text { It has been noted that the obstacles to classroom inquiry include the facilities } \\
\text { needed (Baker, Lang, \& Lawson, 2002; Jackson \& Boboc, 2008) C7a, C7b. }\end{array}$} & NA & II, A, g & $\mathrm{N} / \mathrm{A}$ & 05 \\
\hline $\mathrm{C7b}$ & & NA & II, A, g & $2-3$ & 05 \\
\hline$\overline{\mathrm{C} 8}$ & $\begin{array}{l}\text { Inquiry needs time for students to, for example, design experiments, acquire } \\
\text { materials, collect data, coupled with communicating their findings (Keen-Rocha, } \\
\text { 2005). }\end{array}$ & NA & $\mathrm{I}, \mathrm{B}, \mathrm{d}$ & $\mathrm{N} / \mathrm{A}$ & 05 \\
\hline C9a & \multirow{2}{*}{$\begin{array}{l}\text { In some schools, inadequate managerial support is a constraining factor regarding } \\
\text { the enactment of IBPW (Huziak-Clark et al., 2007; Ramnarain, 2011) C9a, C9b. }\end{array}$} & NA & II, B, k & $4-6$ & 05 \\
\hline$\overline{\mathrm{C} 9 \mathrm{~b}}$ & & $\mathrm{AF}$ & II, B, k & 2 & 05 \\
\hline$\overline{\mathrm{C} 10}$ & $\begin{array}{l}\text { Time constraints may lead teachers to implement the minimum of 'full inquiry' that } \\
\text { is required to satisfy the curriculum requirement on the assessment of practical } \\
\text { investigations (Dai, Gerbino, \& Daley, 2011). }\end{array}$ & AS & $\mathrm{I}, \mathrm{B}, \mathrm{d}$ & $2-3$ & $\mathrm{~N} / \mathrm{A}$ \\
\hline$\overline{\mathrm{C} 11}$ & $\begin{array}{l}\text { Learners with an inadequate knowledge infrastructure, find it a challenge to link an } \\
\text { inquiry question to the associated phenomenon, have difficulties when designing } \\
\text { an experiment, in addition to exhibiting difficulties when handling equipment, } \\
\text { selecting suitable methods, and resolving the technical difficulties arising during } \\
\text { their work (Zion et al., 2007). }\end{array}$ & AS & II, B, j & 3 & 0511 \\
\hline$\overline{\mathrm{C} 12}$ & $\begin{array}{l}\text { Science questions, although rooted in the curiosity of learners, do not freely arise } \\
\text { from them (Chin \& Osborne, 2008). }\end{array}$ & $\mathrm{N} / \mathrm{A}$ & $\mathrm{I}, \mathrm{B}, \mathrm{e}$ & $\mathrm{N} / \mathrm{A}$ & $\mathrm{N} / \mathrm{A}$ \\
\hline$\overline{\mathrm{C} 13}$ & $\begin{array}{l}\text { Inadequacies in prior knowledge and skills, constrained some high school learners } \\
\text { when conducting full inquiry (Gengarelly \& Abrams, 2009). }\end{array}$ & NA & II, B, j & 3 & 05 \\
\hline$\overline{\mathrm{C} 14}$ & $\begin{array}{l}\text { Some teachers cited limitations in classroom space, as a key hindrance associated } \\
\text { with the enactment of IBPW (Kidman, 2012). }\end{array}$ & AS & II, A, g & $4-6$ & 05 \\
\hline C15a & \multirow{2}{*}{$\begin{array}{l}\text { As a result of limitations in laboratory facilities, it is not easy for teachers to have } \\
\text { access to science laboratories for enacting practical work (Higgins, 2009; Kennedy, } \\
\text { 2013) C15a, C15b. }\end{array}$} & EU & II, A, g & 2 & 05 \\
\hline $\mathrm{C} 15 \mathrm{~b}$ & & EU & II, A, g & $\mathrm{N} / \mathrm{A}$ & 05 \\
\hline$\overline{\mathrm{C} 16}$ & $\begin{array}{l}\text { It was found that the new Lebanese science curriculum lacked 'a coherent and well- } \\
\text { thought-out framework regarding inquiry' (BouJaoude cited in Abd-El-Khalick et } \\
\text { al., 2004, p. 400). This was in terms of having only a few broad ideas linked, for } \\
\text { example, to experiments, and process skills, dispersed in the introduction and } \\
\text { objectives for each level of education. }\end{array}$ & AS & $\mathrm{I}, \mathrm{B}, \mathrm{a}$ & $1-3$ & 05 \\
\hline$\overline{\mathrm{C} 17}$ & $\begin{array}{l}\text { Dudu and Vhurumuku (2012) noted in South Africa, that by requiring that only } \\
\text { two practical activities be assessed per grade, the curriculum could be sending a } \\
\text { wrong signal to teachers, who may be misinterpreting this guideline as "Do only } \\
\text { two practicals". }\end{array}$ & $\mathrm{AF}$ & $\mathrm{I}, \mathrm{B}, \mathrm{a}$ & 3 & 053 \\
\hline$\overline{\mathrm{C} 18}$ & $\begin{array}{l}\text { The implementation of IBPW is a challenge in some schools due to the absence of } \\
\text { laboratory assistants (Higgins, 2009). }\end{array}$ & EU & II, B, k & 2 & 05 \\
\hline C19 & $\begin{array}{l}\text { When the teachers attempted to engage several groups of students in the } \\
\text { investigation of a lake ecosystem, they experienced difficulties because they needed } \\
\text { multiple sets of technologies (including a digital titrator, graphing calculators, and } \\
\text { veneer sensors) (Ebenezer, Kaya, \& Ebenezer, 2011). }\end{array}$ & NA & II, A, i & 3 & 05 \\
\hline $\mathrm{C} 20$ & $\begin{array}{l}\text { Investigations have also been found to often lead to new lines of learner questions } \\
\text { that teachers are unwilling or unable to pursue, as the concepts involved were } \\
\text { considered to be inappropriate for the age (Samarapungavan, Mantzicopoulos, \& } \\
\text { Patrick, 2008). }\end{array}$ & NA & $\mathrm{I}, \mathrm{B}, \mathrm{e}$ & 1 & 0511 \\
\hline C21a & \multirow{2}{*}{$\begin{array}{l}\text { Curricula often emphasise learner mastery of content, rather than the enhancement } \\
\text { of their investigative skills (Childs, Tenzin, Johnson, \& Ramachandran, 2012; Dai et } \\
\text { al., 2011) C21a, C21b. }\end{array}$} & AS & $\mathrm{I}, \mathrm{B}, \mathrm{a}$ & $1-3$ & 05 \\
\hline$\overline{\mathrm{C} 21 \mathrm{~b}}$ & & AS & $\mathrm{I}, \mathrm{B}, \mathrm{a}$ & $2-3$ & $\mathrm{~N} / \mathrm{A}$ \\
\hline $\mathrm{C} 22$ & $\begin{array}{l}\text { Aspects of school culture that have been found to serve as a barrier in the } \\
\text { enactment of inquiry in the classroom, include the lack of learner motivation and } \\
\text { inadequate prior experience of inquiry (Gengarelly \& Abrams, 2009). }\end{array}$ & NA & II, B, l & 3 & 05 \\
\hline
\end{tabular}


$\overline{\mathrm{C} 23}$ Time constraints contribute in investigative practical work being limited to only a small number of verified investigations, unconnected to everyday science teaching (Toplis \& Allen, 2012).

C24 School ethos significantly constrains some teachers when using an inquiry-based strategy in practical work (Ramnarain \& Schuster, 2014).

C25 It has been found that some teachers face the lack of valuing of inquiry-based activities, by their colleagues (Huziak-Clark et al., 2007).

C26 The activities in manuals for practical work are usually restricted to structured inquiry (Zion et al., 2007).

$\mathrm{C} 27 \mathrm{a}$ The lack of valuing and pressure from parents could hinder the use of inquiry-

$\overline{\mathrm{C} 27 \mathrm{~b}}$ based activities in classroom (Crawford, 2007; Huziak-Clark et al., 2007) C27a, C27b.

C28 Instructors occasionally avoid inquiry-based activities as a result of limitations in classroom time (Keen-Rocha, 2005).

C29 It has been found that reading literature on scientific inquiry, which is based on reflective or hypothetical-deductive reasoning, can be difficult for young learners (Baker et al., 2002).

C30a Researchers have found that science laboratories are absent or have limitations,

C30b especially in schools in rural settings (Childs et al., 2012; Kriek \& Grayson, 2009;

C30c VanBalkom \& Sherman, 2010) C30a, C30b, C30c

C31 Barriers to student inquiry include the materials needed for the inquiry (Jackson \& Boboc, 2008).

C32 School context is another factor that could inhibit success in teaching science as inquiry (Crawford, 2007).

C33 Allowing students with as much time as they need to create and modify their inquiry plans can be difficult (Jordan et al., 2011).

$\mathrm{C} 34 \mathrm{a}$ Some teachers are constrained by the fact that the skills developed by their learners

$\overline{\mathrm{C} 34 \mathrm{~b}}$ from carrying out open-ended inquiry are either not assessed, or lack adequate

$\overline{\mathrm{C} 34 \mathrm{C}}$ recognition in assessment criteria (Abrahams \& Reis, 2012; Higgins, 2009; Lederman \& Lederman, 2012) C34a, C34b, C34c.

C35 The current standardised-assessment laden educational environment, often requires strategies based on more passive techniques, at the expense of IBPW (Minner, Levy, \& Century, 2010).

C36a There is a short supply of conventional science education materials and equipment

$\overline{\mathrm{C} 36 \mathrm{~b}}$ in many schools in industrialised and developing countries (Kapanadze \& Eilks,

C36c 2014; Qhobela \& Moru, 2014; Singh \& Singh, 2012) C36a, C36b, C36c.

C37 Although the participation of learners in the formulation of a researchable question is crucial in open inquiry, this type of inquiry depends on the cognitive abilities of learners (Zion \& Mendelovici, 2012).

C38 In some classrooms, the enactment of IBPW is being seriously constrained by the lack of prior experience, wherein some learners are easily distracted away from the intended conceptual understanding by apparatus and chemicals (Ramnarain \& Schuster, 2014).

C39 A very high percentage (95.7\%) of surveyed teachers were found to be of the opinion that the integration of inquiry in practical work in the Junior Certificate science programme in Ireland, affected the time needed for course completion and revision (Higgins, 2009).

C40 Teachers noted that the lack of physical resources would be a key hindrance when implementing the inquiry component of Australia's new science curriculum with emphasis on practical work (Kidman, 2012).

C41a It has noted that asking relevant and productive science-related questions is rather

$\overline{\mathrm{C} 41 \mathrm{~b}}$ difficult for learners, especially children of preschool age (Bell, Urhahne, Schanze,

C41c \& Ploetzner, 2010; Ergazaki \& Zogza, 2013; Marbach-Ad \& Sokolove, 2000) C41a, C41b, C41c.

C42a There is the scarcity of inquiry-based activities in some school science textbooks

C42b (Abd-El-Khalick et al., 2004; Crawford, 2016) C42a and C42b.

C43 Teachers of a township school interviewed about learners doing inquiry, cited the large classes they teach as a challenge when interacting with individual learners to scaffold them to conceptual understanding (Ramnarain, 2014). Such classes cause teachers to resort to didactic pedagogy.

C44 The successful enactment of inquiry-based science projects, tends to require extended professional support, even in the case of experienced educators (Lederman \& Lederman, 2012).

C45 The unavailability of equipment (e.g., hot plate), limits the investigations that teachers can allow their learners to perform (Capobianco \& Thiel, 2006).

C46a Young children may not have the cognitive resources that adults or scientists

$\overline{\mathrm{C} 46 \mathrm{~b}}$ possess, in relation to designing controlled experiments and evaluating how their

C46c models fit the associated data (Klahr, 2000; Kuhn \& Dean, 2004; Masnick \& Klahr, 2003) C46a, C46b, C46c.

C47 It has been claimed that finding genuinely open-ended problems that can be investigated in the classroom is difficult (Kind et al., 2011).

$\begin{array}{llll}\text { EU } & \text { I, B, d } & 2-3 & 05\end{array}$

\begin{tabular}{cccc} 
AF & II, B, l & 3 & 053 \\
NA & II, B, k & $4-6$ & 05 \\
& & & \\
AS & I, A, c & 3 & 0511 \\
& & & \\
\hline NA & II, B, k & $4-6$ & 05 \\
\hline NA & II, B, k & $4-6$ & 05 \\
\hline NA & I, B, d & N/A & 05 \\
NA & I, B, e & N/A & 05
\end{tabular}

\begin{tabular}{|c|c|c|c|}
\hline AS & II, A, g & $1-3$ & 05 \\
\hline $\mathrm{AF}$ & II, A, g & $4-6$ & 053 \\
\hline AS & II, A, g & $\mathrm{N} / \mathrm{A}$ & $\mathrm{N} / \mathrm{A}$ \\
\hline NA & II, A, i & $2-3$ & 05 \\
\hline
\end{tabular}

\begin{tabular}{|c|c|c|c|}
\hline NA & II, B, I & $4-6$ & 05 \\
\hline NA & $\mathrm{I}, \mathrm{B}, \mathrm{d}$ & $4-6$ & 05 \\
\hline EU & $\mathrm{I}, \mathrm{B}, \mathrm{b}$ & $1-2$ & 05 \\
\hline$\overline{\mathrm{EU}}$ & $\mathrm{I}, \mathrm{B}, \mathrm{b}$ & 2 & 05 \\
\hline $\mathrm{N} / \mathrm{A}$ & $\mathrm{I}, \mathrm{B}, \mathrm{b}$ & N/A & $\mathrm{N} / \mathrm{A}$ \\
\hline NA & $\mathrm{I}, \mathrm{B}, \mathrm{b}$ & $1-3$ & 05 \\
\hline
\end{tabular}

\begin{tabular}{|c|c|c|c|}
\hline $\mathrm{N} / \mathrm{A}$ & II, A, i & $\mathrm{N} / \mathrm{A}$ & N/A \\
\hline $\mathrm{AF}$ & II, A, i & $2-3$ & 0533 \\
\hline $\mathrm{AF}$ & II, A, i & $4-6$ & 05 \\
\hline AS & II, B, j & 3 & 0511 \\
\hline
\end{tabular}

(1)

$\begin{array}{llll}\text { AF } & \text { II, B, j } & 3 & 053\end{array}$

$\begin{array}{llll}\text { EU } & \text { I, B, d } & 2 & 05\end{array}$




\begin{tabular}{|c|c|c|c|c|c|}
\hline \multicolumn{6}{|l|}{ Legend: } \\
\hline $\bar{a}$ & $\mathrm{~b}$ & e & & $\mathrm{d}$ & \\
\hline $\mathrm{AF}=$ Africa & $\mathrm{I}$ = System-Level & 1 & $=$ Primary education & 0511 & $=$ Biology \\
\hline AS = Asia & II = School-Level & 2 & $=$ Lower secondary education & 0512 & $=$ Biochemistry \\
\hline $\mathrm{EU}=$ Europe & $\mathrm{A}=$ Material-Related & 3 & $=$ Upper secondary education & 0521 & $=$ Environmental sciences \\
\hline NA $=$ North America & $\mathrm{B}=$ Non-Material-Related & $4-6$ & $=$ Post-secondary non-tertiary & 0522 & $=$ Natural environments and \\
\hline $\mathrm{OC}=$ Oceania $/$ Australia & $\mathrm{a}=$ Curriculum design & & education to Bachelor level & & wildlife \\
\hline SA $=$ South America & $\mathrm{b}=$ Assessment practices & & education and equivalent & 0531 & $=$ Chemistry \\
\hline & $\mathrm{d}=$ Time constraints & & & 0533 & $=$ Physics \\
\hline & $\mathrm{e}=$ Developmental age & & & 053 & $=$ Physical sciences \\
\hline & $\mathrm{f}=$ Teacher education & & & 05 & $=$ General science, primary \\
\hline & $\mathrm{g}=$ Classroom and laboratory facilities & & & & science, or integrated science \\
\hline & $\mathrm{h}=$ Large classes & & & & \\
\hline & $\mathrm{i}=$ Physical resources & & & & \\
\hline & $\mathrm{j}=$ Learner-related difficulties & & & & \\
\hline & $\mathrm{k}=$ Teacher support & & & & \\
\hline
\end{tabular}

e N/A = Not Applicable (e.g., in the case of a review paper) or Not Available

f NA is not to be mistaken for N/A

\section{http://www.ejmste.com}

